
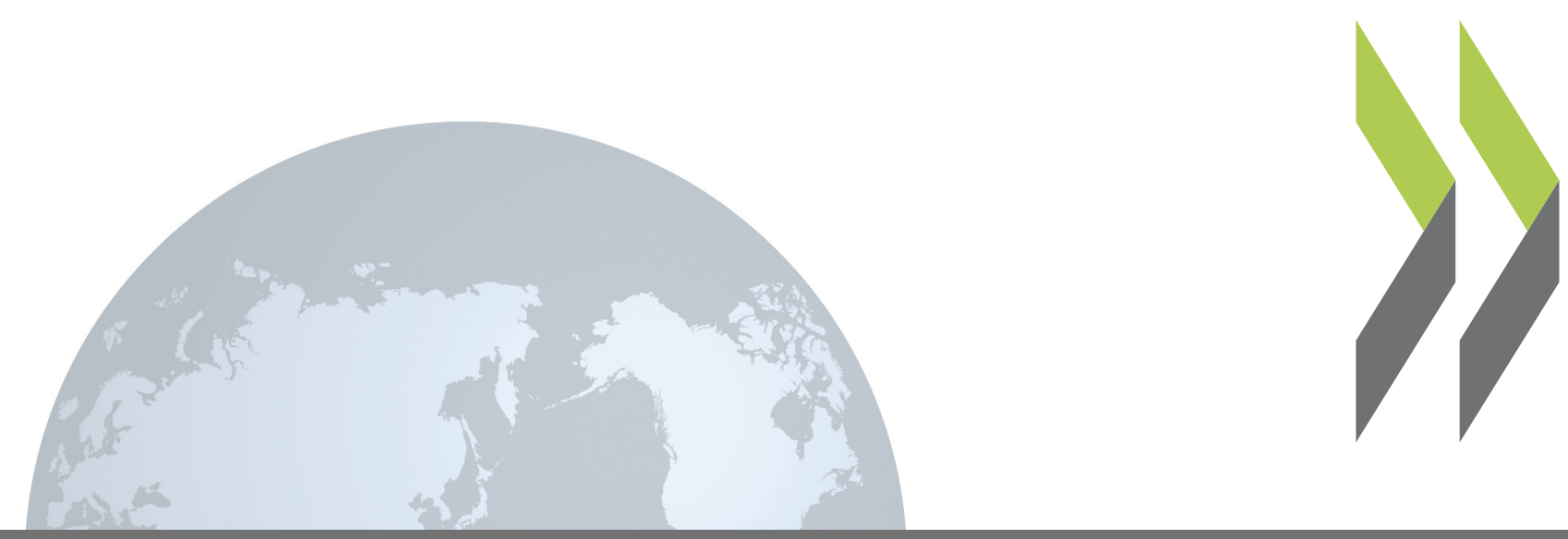

OECD Working Papers on Finance, Insurance and Private Pensions No. 23

\title{
The Role of Institutional Investors in Financing Clean Energy
}

\section{Christopher Kaminker,} Fiona Stewart 


\section{OECD WORKING PAPERS ON FINANCE, INSURANCE AND PRIVATE PENSIONS}

OECD Working Papers on Finance, Insurance and Private Pensions provide timely analysis and background on industry developments, structural issues, and public policy in the financial sector, including insurance and private pensions. Topics include risk management, governance, investments, benefit protection, and financial education. These studies are prepared for dissemination in order to stimulate wider discussion and further analysis and obtain feedback from interested audiences.

The papers are generally available only in their original language English or French with a summary in the other if available.

\section{OECD WORKING PAPERS ON FINANCE, INSURANCE AND PRIVATE PENSIONS}

are published on www.oecd.org/daf/fin/wp

This document and any map included herein are without prejudice to the status of or sovereignty over any territory, to the delimitation of international frontiers and boundaries and to the name of any territory, city or area.

Ce document et toute carte qu'il peut comprendre ne préjugent en rien du statut de tout territoire, de la souveraineté s'exerçant sur ce dernier, du tracé des frontières et limites internationales, et du nom de tout territoire, ville ou région. 


\title{
Abstract \\ THE ROLE OF INSTITUTIONAL INVESTORS IN FINANCING CLEAN ENERGY
}

\author{
by Christopher Kaminker and Fiona Stewart
}

\begin{abstract}
Decarbonising the world's energy system, moving towards a resource efficient economy and providing energy access for all will require doubling existing investment levels to around USD 2 trillion a year or $2 \%$ of GDP. Governments understand that large sums of capital will be required, and many are also realising the need for further recourse to private capital as public finances have become strained in many developed countries. Simultaneously, banking sector provision of long-term finance has become tighter due deleveraging and new financial regulations. With their USD 71 trillion in assets, institutional investors potentially have an important role to play. Given the current low interest rate environment and weak economic growth prospects in many OECD countries, institutional investors are increasingly looking for real asset classes which can deliver steady, preferably inflation-linked, income streams with low correlations to the returns of other investments. Clean energy projects may combine these sought-after characteristics.
\end{abstract}

Yet - outside the major pension funds and insurance companies - institutional investor allocations to clean energy projects remain limited, particularly when it comes to the types of direct investment which can help close the financing gap. Reasons for institutional investor hesitancy include a lack of information and expertise when it comes to the type of direct infrastructure investment required to finance clean energy projects, and a potentially unsupportive regulatory backdrop. These problems are compounded by a lack of suitable investment vehicles providing the risk/return profile that institutional investors need to manage the risks specific to clean energy projects. There are many species of risk, including regulatory risk stemming from a lack of clarity in terms of environmental and climate policy, and retroactive changes to support mechanisms. Progress is being made - with investor groups coming together to use their scale and build their expertise in clean energy investment. From the public and private sectors, actions are underway to scale up green bond offerings, create risk-mitigating public finance mechanisms and co-investment funding structures. These initiatives need to be encouraged, carefully monitored, and expanded where successful.

JEL codes: $G 15, G 18, G 23, G 28, J 26$

Keywords: pension funds, insurance companies, green bonds, infrastructure, green growth

\footnotetext{
* Christopher Kaminker is an economist in the Director's Office of the OECD's Environment Directorate. Fiona Stewart is a principal administrator in the Financial Affairs Division of the OECD's Directorate for Financial and Enterprise Affairs. The views expressed are the sole responsibility of the authors and do not reflect those of their organisations or the governments of OECD Member countries. The authors are solely responsible for any errors.
} 


\section{Acknowledgements}

The authors would like to thank their colleagues Raffaele Della Croce, Jan Corfee-Morlot, Alexis Nikolakopolus, Simon Upton, Helen Mountford, Jagoda Sumicka, Virginie Marchal, Andrew Prag, Geraldine Ang, Jane Ellis, Christopher Kennedy, Gregory Briner and Arthur Mickoleit at the OECD along with Cecilia Tam and Lisa Ryan at the IEA who provided valuable comments and review.

We would also like to thank the following expert reviewers for their input, comments and guidance: Julian Richardson and Nick Percival (Parhelion Underwriting), Michael Liebreich, William Young and Abraham Louw (Bloomberg New Energy Finance), Mike Wilkins (S\&P), Craig Mackenzie (SWIP), Fred Kittler and Kelsey Lynn (Firelake Capital), Paul Chambers (UK DECC), Michael Eckhart and Aakash Doshi (Citigroup), Sean Kidney and Padraig Oliver (Climate Bonds Initiative), Glenn Fox (Hadrian's Wall Capital), Charles Thomas (Jupiter Fund Management), Tony Lent (Wolfensohn Fund Management), Mario Chisholm (Och-Ziff Capital Management), Torben Moger Pedersen (PensionDanmark), Mohamed Al Bader and Michel Ellis (Masdar Capital), Rory O'Connor (Blackrock), Steven Ferrey (Suffolk Law School), Albert Bressand (Columbia University), Øystein Stephansen (DNB Bank), Imtiaz Ahmad (Morgan Stanley) and Mark Fulton (Deutsche Bank). 


\section{Résumé}

\section{LE RÔLE DES INVESTISSEURS INSTITUTIONNELS DANS LE FINANCEMENT DES ÉNERGIES PROPRES}

Pour décarboner le système énergétique mondial, et éviter ainsi de pérenniser les technologies polluantes et les niveaux d'émissions inacceptables, il faudra doubler les investissements actuels pour les porter à 2000 milliards USD environ par an, soit $2 \%$ du PIB. Conscients de l'ampleur des sommes nécessaires et face aux contraintes qui pèsent sur les finances publiques dans de nombreux pays développés, les États envisagent de recourir davantage aux capitaux privés. Parallèlement, on assiste à une contraction de l'offre de capitaux longs de la part d'un secteur bancaire engagé dans un processus de réduction de l'effet de levier et de mise en œuvre des nouvelles réglementations financières. Dans ce contexte, les investisseurs institutionnels, qui disposent de 7100 milliards USD d'actifs, peuvent avoir un rôle important à jouer. Compte tenu de la faiblesse actuelle des taux d'intérêt et de la morosité des perspectives de croissance économique dans la plupart des pays de l'OCDE, les investisseurs institutionnels cherchent de plus en plus à investir dans des actifs physiques, susceptibles de dégager des revenus stables, de préférence indexés sur l'inflation, et faiblement corrélés aux rendements des autres types d'investissements. Les projets dans le domaine des énergies propres peuvent répondre à ces critères.

Pour autant, dans les stratégies d'allocations d'actifs des investisseurs institutionnels - à l'exception des grands fonds de pension et sociétés d'assurance-, ces projets restent peu présents, en particulier lorsqu'il s'agit des formes d'investissements directs qui pourraient contribuer à combler l'insuffisance de financements. Parmi les raisons expliquant l'hésitation des investisseurs institutionnels figurent d'une part un manque d'information et de connaissance des différentes formes d'investissement direct dans des infrastructures permettant le financement des projets d'énergies propres, et, d'autre part, un environnement réglementaire peu favorable. À ces obstacles s'ajoute l'absence de véhicules d'investissement adaptés offrant le profil risque/rendement dont les investisseurs institutionnels ont besoin pour gérer les risques propres à ces projets. En effet, les projets dans le domaine des énergies propres présentent des risques de différentes natures, et notamment d'ordre réglementaire, $\mathrm{du}$ fait de l'opacité des politiques environnementales et climatiques, et des modifications rétroactives apportées aux dispositifs de soutien. On observe toutefois quelques avancées : des investisseurs se regroupent pour bénéficier d'un effet d'échelle et renforcer leurs compétences en matière d'investissement dans les énergies propres. Dans le secteur public, des actions sont en cours pour étoffer l'offre d'obligations vertes et mettre en place des dispositifs de financement public limitant les risques et des structures de co-investissement. Ces initiatives doivent être encouragées, faire l'objet d'un suivi minutieux, et, si elles s'avèrent performantes, développées.

Codes JEL: G15, G18, G23, G28, J26

Mots clés: fonds de pension, obligations vertes, infrastructure, croissance verte 


\section{TABLE OF CONTENTS}

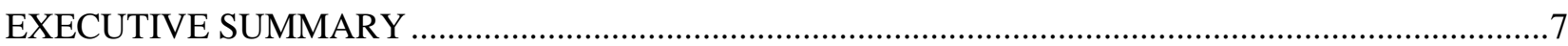

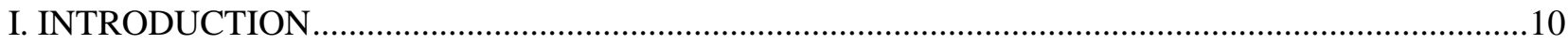

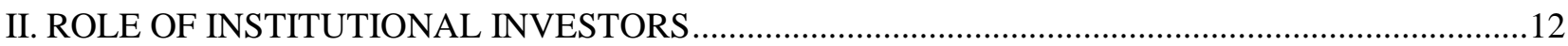

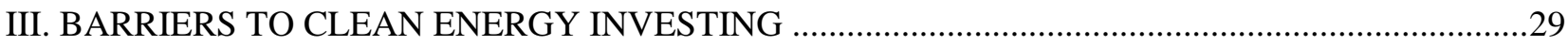

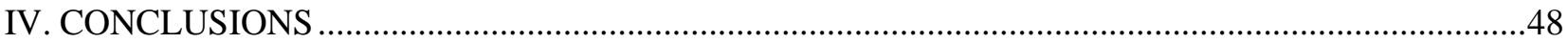

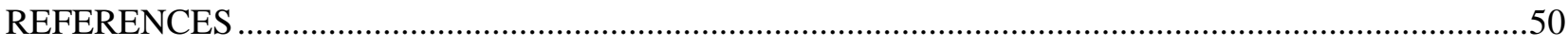

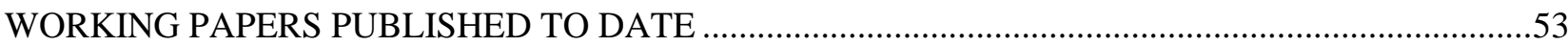

\section{Tables}

Table 1. Institutional Investors Climate Change Groups.................................................................19

Table 2. Barriers to Institutional Investors Allocation to Infrastructure .............................................30

Table 3. The double challenge of low-carbon, climate-resilient infrastructure projects:

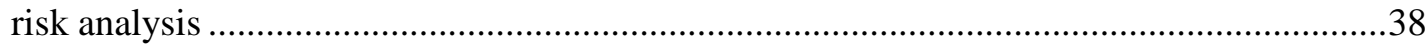

\section{Figures}

Figure 1. Total investment requirements in the power sector 2010-2020........................................11

Figure 2. Relative Share and Total Assets by Type of Institutional Investors in OECD (1995-2010).13

Figure 3. Change in Gross Fixed Capital Formation vs. Reduction in Green House Gases for Energy and Industry sectors, 1997-2007 (OECD countries and CEM Countries in RED) ................16

Figure 4. Main Institutional Investors' Financing Vehicles for Infrastructure Investment...................18

Figure 5. Clean energy asset financing where pension funds have been involved

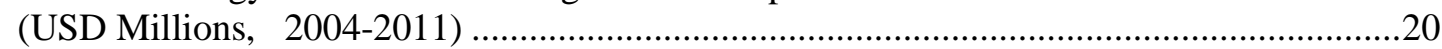

Figure 6. Clean energy asset financing where insurance companies have been involved (USD Millions, 2004-2011) ...............................................................................................23

Figure 7. Sources of infrastructure financing - Estmimate for Developed Economies ........................29

Figure 8. Pension fund and direct insurers asset allocation for selected investment categories in selected OECD countries, 2010 ......................................................................................

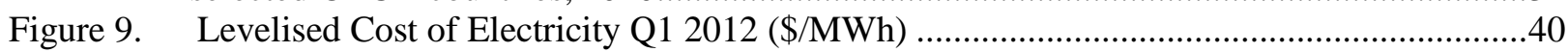

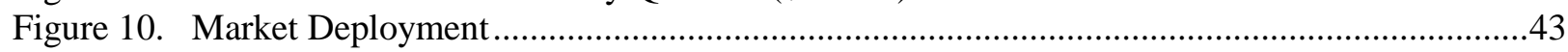

Figure 11. Elements of an Integrated Domestic Policy Framework for Green Infrastructure Investment.

\section{Boxes}

Box 1. How much is available for long-term investment?................................................................

Box 2. Examples of Pension Funds' Investments in Clean Energy Projects ...........................................21

Box 3. Examples of Insurance Companies' Investments in Clean Energy Projects ..................................24

Box 4. Examples of Sovereign Wealth Funds' Investments in Clean Energy Projects ............................26

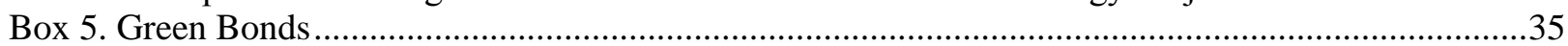

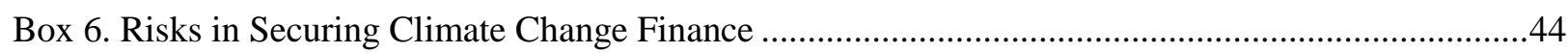

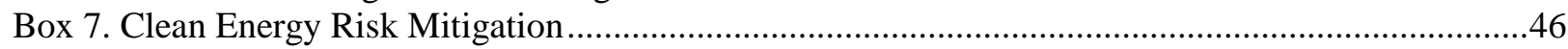




\section{EXECUTIVE SUMMARY}

Decarbonising the world's energy system, moving towards a resource efficient economy and providing energy access for all will require enormous investments. Achieving this economy-wide transformation will require cumulative investment in green infrastructure in the range of USD 36-42 trillion between 2012 and 2030, i.e. approximately USD 2 trillion or 2\% of global GDP per year. Today, only USD 1 trillion is being invested annually. Therefore, a USD 1 trillion investment gap exists that needs to be addressed.

In the nearer term, and focusing on the power sector alone, the IEA projects that USD 6.35 trillion in total investment will be required from 2010-2020 to reduce energy related $\mathrm{CO}_{2}$ emissions 50\% by 2050 compared to 2005 levels. Decarbonising the power sector in this manner will require switching from traditional fossil-fuel plants to a mix of renewables, nuclear and fossil-fuel plants equipped with carbon capture and storage. The OECD 'Environmental Outlook to 2050' projects that in the absence of new policies, energy-related $\mathrm{CO}_{2}$ emissions are expected to grow by $70 \%$ by 2050 .

These are formidable numbers, but such investment levels are well within the capacity of capital markets if the risk-adjusted returns are available. Many governments are realising that further recourse to private capital is required, as public finances have become strained and in many developed countries banking sector provision of long-term finance has become tighter. With their USD 71 trillion in assets, institutional investors - including pension funds and insurance companies - potentially have an important role to play in financing clean energy programmes.

This is a potentially 'win win' situation. Given the current low interest rate environment and weak economic growth prospects in many OECD countries, institutional investors are increasingly looking for 'real' asset classes which can deliver steady, preferably inflation adjusted, income streams with low correlations to the returns of other investments. Clean energy projects can provide institutional investors with investments which potentially combine these sought-after characteristics. They can offer stable and predictable cash flows (when backed by long-term contracts with investment grade counterparties), often with inflation protection (e.g. with indexed tariffs). Wind and solar projects typically have a lifespan of around 25 years, with manufacturer warranties, long-term contracts with power purchasers and government support. This also suits the long-term investment horizons of this class of investors. Further, the cost of clean energy technologies continues to decrease and efficiencies have scaled up. Solar panels have decreased in cost by $75 \%$ in three years. At the same time, given the structure of their liabilities, institutional investors have the capacity to take on term and illiquidity risk prevalent in infrastructure investments.

OECD estimates that less than $1 \%$ of pension funds' assets globally are allocated directly to infrastructure investment, let alone to clean energy projects. Likewise, insurance companies' direct allocations to infrastructure projects remain in the billions of dollars, compared with total industry assets of around USD 19.3 trillion. That said, institutional investor interest in the clean energy sector is starting to develop, and they are slowly starting to be attracted to climate change and resource efficiency-related financial products, which can help finance projects with a positive environmental impact while remaining appealing from a financial return perspective. Some of the world's leading pension funds and insurance companies have already made significant investments and future commitments to clean energy projects. 
Given the scale of the USD 71 trillion in capital in the hands of institutional investors and evidence of an emerging interest on their part for clean energy investments, an important question for policy makers is which potential barriers may be preventing institutional investors from significantly scaling up their commitments.

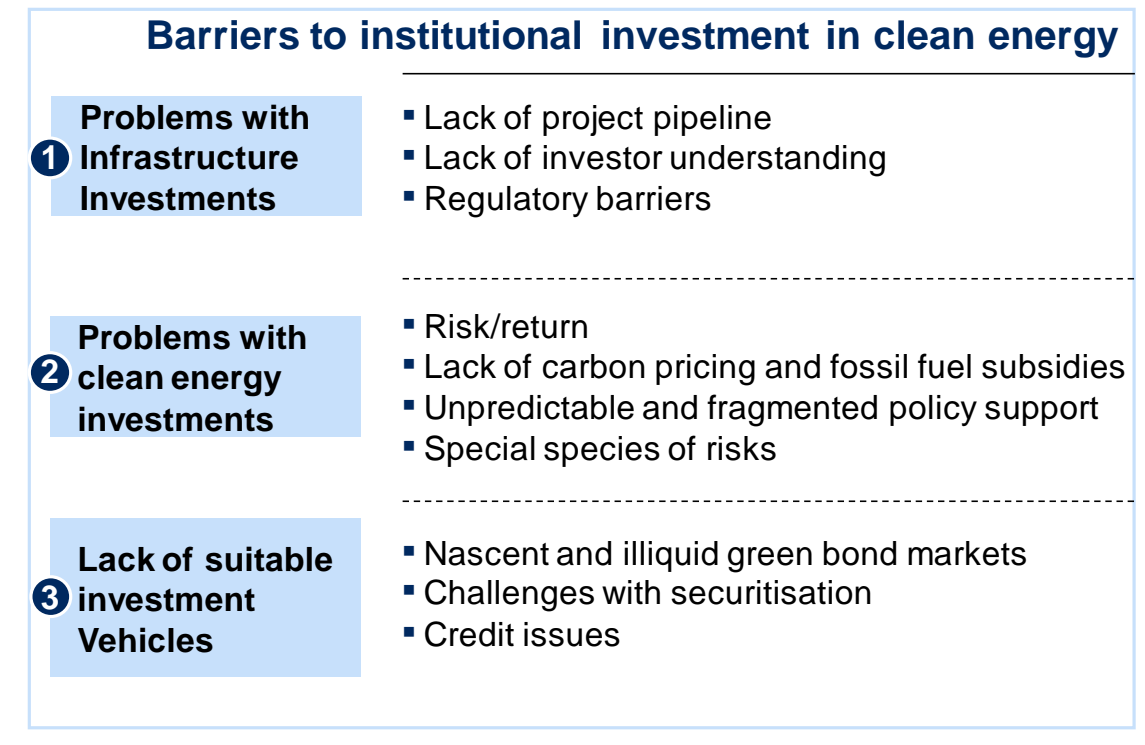

\section{Problems with Infrastructure Investments}

Given that clean energy assets are basically a subset of infrastructure investments, it is important to first consider why institutional investors have limited allocations to this sector, before trying to understand their reservations towards green projects such as clean energy. There are multiple barriers to infrastructure investing. These include:

- Lack of a pipeline of infrastructure projects planned by governments and the potential for policy priorities to change;

- Lack of investor capability and understanding of the risks specific to infrastructure investing, and lack of data to assess this asset class;

- Regulatory barriers, such as mark to market accounting and solvency rules, which can act as disincentives to long-term investing;

- $\quad$ Lack of suitable investment vehicles - particularly collective debt instruments with suitable scale, satisfactory rating and liquidity.

\section{Problems with Clean Energy Investments}

There are also issues specific to clean energy investments which are acting as barriers to institutional investors. These include:

- Unsupportive environmental policy backdrop;

- Lack of carbon price and/or presence of harmful subsidies, which cause the mispricing of clean energy investments vs. existing, polluting technologies; 
- Policy risk derived from regulatory uncertainty;

- Specific risks related to clean energy projects, including technology risk, which make it difficult to achieve investment grade ratings.

Governments have started to make progress when it comes to supporting institutional investors' capital allocations to clean energy projects but more needs to be done if the transition to a lower carbon and resource efficient economy is to be effected. Ministers can take a lead in encouraging further efforts to support institutional investors financing in the clean energy space - by providing clearer support in terms of the environmental policy backdrop in general (through a carbon price and /or the redirection of fossil fuel subsidies), through transparent and stable support for clean energy projects, and through dramatically increasing efforts to pool public funding to leverage private investments, in part by scaling up risk mitigation, credit enhancement and co-investment funding structures.

Ministers can also work more closely with the institutional investors themselves to better understand their needs. This requires improving the data and monitoring of their clean energy investments, including international harmonisation, performance measurement and rating approaches for alternative investments in general and green investments in particular. Ministers need to work with their colleagues in finance ministries to ensure that the investment and regulatory environment is supportive and that institutional investors are offered appropriately structured financing vehicles.

In order to achieve the goal of encouraging further investment in clean energy projects by institutional investors, further discussion and analysis could centre around the following questions:

- What are the most efficient and effective financing tools, public finance mechanisms (PFMs), co-funding structures and credit enhancement tools for leveraging private sector financing? How can successful experience with such tools and mechanisms be scaled up and applied more widely?

- What are the implications of financial regulations such as Basel III and Solvency II for the financing of clean energy? How can governments and financiers work together to address any possible constraints they might impose?

- Given that bonds remain the dominant asset class for institutional investors, which mechanisms could governments provide to increase fixed income allocation to green investments? How can securitisation be harnessed to scale up the green bond markets?

- $\quad$ Are standards for clean energy investment vehicles required? If so, who might play a useful role to move these forward? How can data be better collected and monitored to provide transparency about the performance of green investments?

The OECD continues to work in these areas ${ }^{1}$ and it is hoped that this report will provide a platform to spark further ideas and debate on the topic.

1 Notably the Organisation has drafted policy actions to support pension fund investment in green infrastructure for the June 2012 G20 Leaders' Summit. 


\section{INTRODUCTION}

This report examines the potential role that institutional investors ${ }^{2}$ can play in providing much needed financing for clean energy investments. It also sheds light on the current patterns of investment allocations when it comes to clean energy investments. The report proceeds to examine the barriers which are preventing institutional investors from providing such financing on the scale required, and concludes by offering some discussion points around how such challenges can be addressed.

The report builds on extensive previous and on-going work of the OECD in the area of 'green growth ${ }^{3}$ The focus is on the role of institutional investors, again building on OECD work in this area. ${ }^{4}$ For the purpose of this report, 'green growth' is about pursuing economic growth and development while preventing environmental degradation, biodiversity loss and unsustainable natural resource use. Access to energy plays a crucial role in securing human well being. For the purpose of this report, clean energy refers to the BNEF definition which includes bio energy, geothermal, hydro, marine, solar, wind and energy smart technologies. ${ }^{5}$

By 2050, the Earth's population is expected to increase from 7 billion to over 9 billion and the world economy is expected to nearly quadruple, and is projected to use $80 \%$ more energy. According to the OECD's recently published 'Environmental Outlook to 2050' (OECD 2012), without more effective policies, the share of fossil-fuel based energy in the global energy mix will still remain at about $85 \%$, with global GHG emissions projected to increase by $50 \%$, primarily due to a $70 \%$ growth in energy-related $\mathrm{CO}_{2}$ emissions. In this scenario, the atmospheric concentration of GHGs could reach 685 parts per million (ppm). As a result, the global average temperature increase could be $3^{\circ} \mathrm{C}$ to $6^{\circ} \mathrm{C}$ above pre-industrial levels by the end of the century, exceeding the internationally agreed goal of limiting it to below $2^{\circ} \mathrm{C}$. ${ }^{6}$ For this reason, clean energy becomes absolutely critical to any strategy to alter these trends.

It is estimated that transitioning to a low-carbon, climate resilient (LCCR) and resource efficient economy, and more broadly 'greening growth' over the next 10 years will require significant investment which the IEA see in the order of USD 24 trillion by 2020 (IEA, 2012 - forthcoming). Transforming infrastructure to be LCCR is a critical part of the climate policy challenge because it will lock-in development patterns and because it represents the bulk of the investment needed to achieve the $2{ }^{\circ} \mathrm{C}$ target. The IEA suggests that $80 \%$ of projected global $\mathrm{CO}_{2}$ energy emissions to 2020 are already locked-in through the world's current infrastructure asset base. Infrastructure assets have long operational lifetimes (the estimated average lifetime of a coal-fired power station is $40-60$ years). About $60 \%$ of power plants in service or under construction today are projected to still be in operation in 2035, which will mean that the majority of power sector emissions in that year are already "locked in", unless future policy changes force early retirement of existing plants or their retrofitting with carbon capture and storage (CCS). Unless clean

2 Though the term 'institutional investor' covers a wide range of organisations (including endowments and foundations, sovereign wealth funds etc.), the focus of the report is on pension funds and insurance companies as the OECD is the leading organisation collecting statistics on these institutions, has been undertaking extensive analysis on their investments and is currently drafting policy options relating to pension funds and green infrastructure to be discussed at the G20 Leaders Summit in June 2012.

3 See www.oecd.org/greengrowth and for example - OECD, (2012a - forthcoming), 'Towards a Policy Framework Green Infrastructure Investment' or OECD, (2012b - forthcoming), 'Defining and Measuring Institutional Investors' Allocations to Green Investments'

$4 \quad$ See OECD project on long-term investing www.oecd.org/finance/lti and OECD, (2011), 'The Role of Pension Funds in Financing Green Growth Initiatives'

5 See BNEF: http://bnef.com/markets/

6 See OECD (2011a), 'Towards Green Growth', OECD/IEA (2011b), OECD Green Growth Studies: Energy. 
alternatives become more competitive, such stations will be run for the duration of their economic lives. In addition, a substantial proportion of infrastructure built in the next five years, will still be in use long after 2030. The challenge policy makers face is that new capacity will be built either way. Clean energy technologies, when coupled with supportive policies, can significantly reduce carbon pollution from traditional fossil fuels, improve air quality, create jobs, enhance energy security, and provide improved access to energy around the world. Appropriate policies and international co-operation are needed now to prevent further lock-in of polluting technologies and to bend the emissions trajectory downwards, particularly in regions where modern infrastructure remains to be built.

Decarbonising the world's energy system will require enormous investments. Achieving this economy-wide transformation requires cumulative investment in green infrastructure in the range of USD 36-42 trillion between 2012 and 2030, i.e. approximately USD 2 trillion or 2\% of global GDP per year. Today, only USD 1 trillion is being invested annually. As such, a USD 1 trillion investment gap exists which would need to be addressed. ${ }^{7}$

In the nearer term and just focusing on the power sector alone, the IEA (2012 forthcoming) projects that USD 6.35 trillion in total investment will be required between 2010-2020 in order to reduce energy related emissions by 50\% compared to 2005 levels. Decarbonising the power sector in this manner will require switching from traditional fossil-fuel plants to a mix of renewables, nuclear and fossil-fuel plants equipped with CCS. The investment requirements rise rapidly between 2030 to 2050 . These are formidable numbers but well within the capacity of capital markets if the risk-adjusted returns are available.

Figure 1. Total investment requirements in the power sector $\mathbf{2 0 1 0 - 2 0 2 0}$

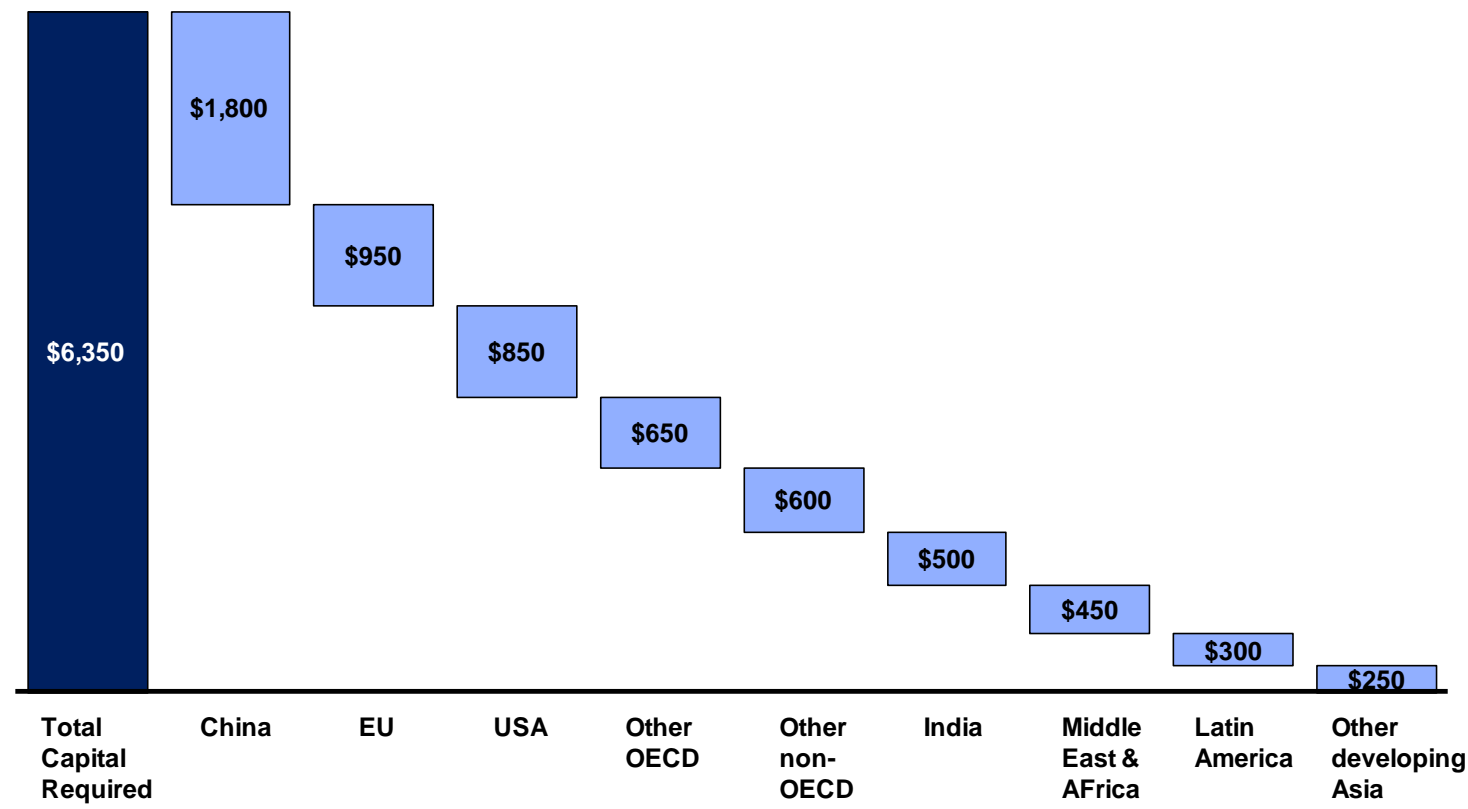

Source: OECD chart based on IEA data; IEA (2012), Tracking Clean Energy Progress: Energy Technology Perspectives 2012 excerpt as IEA inputs to the Clean Energy Ministerial, OECD/IEA, Paris

7 B20 Task Force on Green Growth Recommendations to the G20 Los Cabos Meeting (2012, forthcoming); Calculation based on World Economic Forum Analysis; HSBC, Sizing the climate economy, 2010; HSBC, A Climate for Recovery, 2009; BCG, The Global Infrastructure Challenge, 2010. 


\section{ROLE OF INSTITUTIONAL INVESTORS}

\section{What is the Potential Role of Institutional Investors?}

There is already international agreement on the need to increase financing for climate change mitigation and adaptation - including funding for clean energy projects. Indeed in the international climate change negotiations, developed countries have committed to mobilising jointly USD 100 billion per year by $2020^{8}$ - but key questions remain regarding what financial flows might count towards this commitment and how this will be delivered in practice. ${ }^{9}$

At the same time, traditional sources of private finance for infrastructure projects, including clean energy, are becoming more constrained in their capacity to provide long term capital. For example, it has become more difficult to obtain bank loans with the long maturities required by infrastructure projects as commercial banks face capital and liquidity constraints. The new Basel III banking regulations are expected to have a very negative impact on the type of long-term project financing required to fund clean technology. The new requirements will force banks to hold more equity on their balance sheets for higher risk lending and it is predicted that the long-term capital commitments associated with clean energy infrastructure projects could become too expensive for banks to finance. Current expectations are that conditions for bank loans and refinancing will likely become much less favourable and more expensive.

Some of the finance community have stressed that there is a need for detailed appraisal of the implications of Basel III for banks ability to provide long-term project finance; and further consideration of whether there are ways for this impact to be ameliorated via modifications to the Basel III regulations. Indeed, following the financial crisis, some of the banks most active in the infrastructure financing sector more broadly have largely withdrawn from the market, essentially due to liquidity issues and the fact that these loans consume a lot of capital but are relatively low in profits. ${ }^{10}$ In addition, the Dodd Frank Wall Street Reform and Consumer Protection Act passed by the US Congress in 2010 could potentially restrict investment in private equity and venture capital firms and other types of privately offered funds which may have an impact on US banks' ability to fund the development of clean tech companies. ${ }^{11}$

The demise of AAA-rated monoline insurance companies ${ }^{12}$ has also frozen capital markets for infrastructure, depriving the infrastructure market of a limited but valuable source of financing (by 2010 only one monoline insurer was issuing new policies and none had retained a AAA credit rating). ${ }^{13}$ This gap has been partially filled by multi-lateral lending institutions increasing their support to the infrastructure sector during the crisis, but by themselves they cannot offer a solution to the 'infrastructure gap' more broadly or all the funds required for clean energy projects more specifically.

8 The Cancun agreements recognised the commitment of developed countries to a goal of "mobilising jointly $\$ 100$ billion per year by 2020 to address the needs of developing countries...from a variety of sources, public and private, bilateral and multilateral, including alternative sources" (UN AGF, 2010).

9 OECD (2012c) 'Tracking Climate Finance: What and How?

10 In the current environment, the 15-year project finance debt market from European banks is virtually nonexistent (having moved to 7-10 year structure as funding beyond this period is prohibitively expensive), although some Asian banks and some export credit agencies are still active (HgCapital).

11 For further details see Standard \& Poor's (2011) 'Basel III and Solvency II Regulations Could Bring a Sea Change in Global Project Finance Funding'.

12 Monolines are specialised insurance companies which provide guarantees and thereby credit enhancement to bond issuers.

13 See HSBC and Climate Bonds Initiative (forthcoming) http://ftalphaville.ft.com/blog/2010/10/26/382806/deaththroes-of-the-monolines/ 
Though governments understand that decarbonising the economy will require large sums, many are also realising that further recourse to private capital is required. With their USD 71 trillion in assets, institutional investors - including pension funds and insurance companies - potentially have an important role to play in financing clean energy projects.

Figure 2. Relative Share and Total Assets by Type of Institutional Investors in OECD (1995-2010) ${ }^{14}$

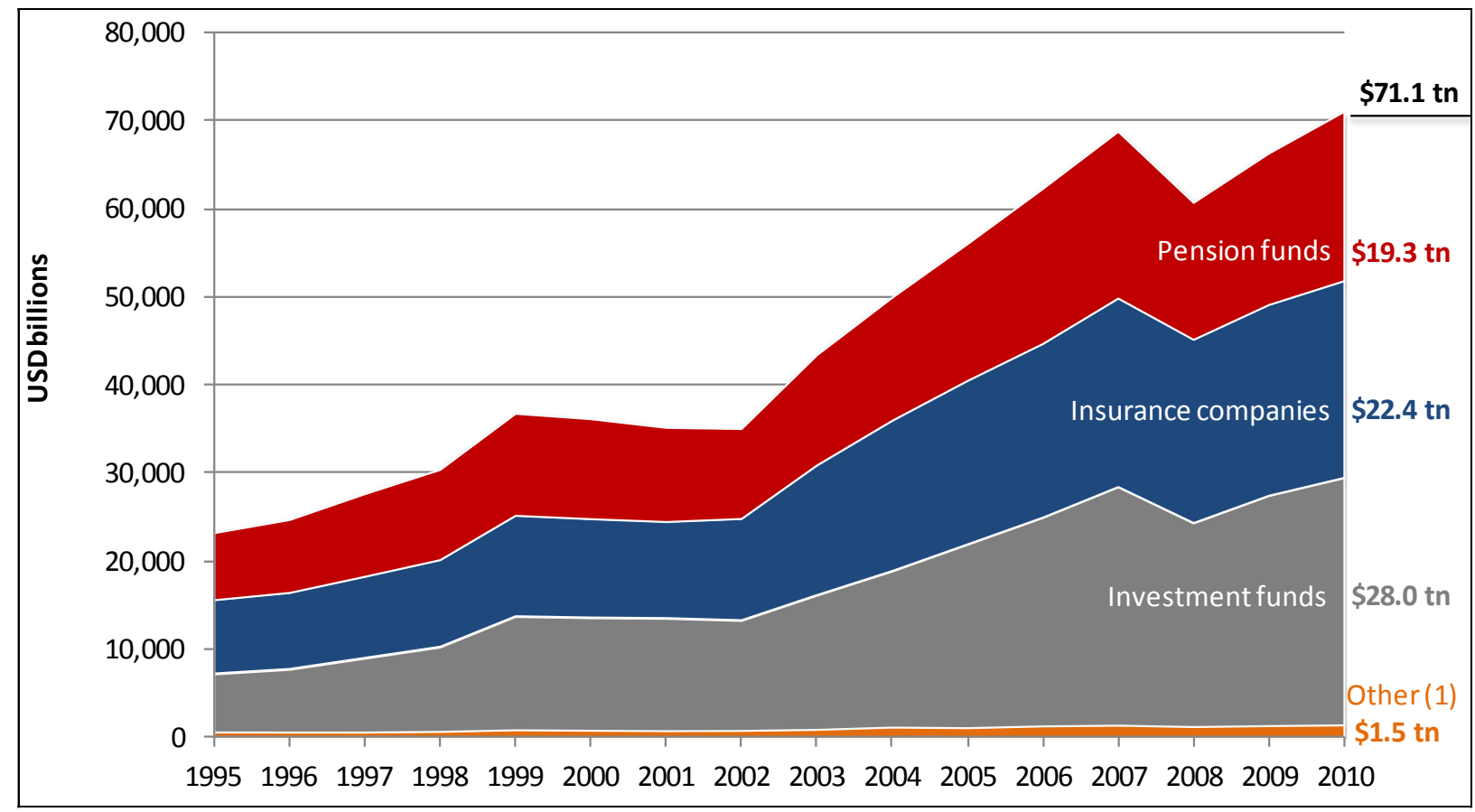

Source: OECD Global Pensions Statistics and Institutional Investors databases and OECD estimates ${ }^{15}$

This is a potentially 'win win' situation as, given the current low interest rate background and weak economic growth prospects in many OECD countries, institutional investors are increasingly looking for asset classes which can deliver low-correlation, steady, preferably inflation-linked, income streams.

Infrastructure projects in general have the potential to deliver attractive risk-adjusted returns to these long-term investors, which have liabilities and funding requirements which can stretch over decades. Clean energy projects can in particular provide institutional investors with investments which may combine these sought-after characteristics. Projects that are "bankable"16 can offer stable and predictable cash flows (renewable energy is not subject to fuel price volatility and is backed by long-term contracts with investment grade counterparts ${ }^{17}$ ), often with inflation protection. ${ }^{18}$ Wind and solar projects also have an

14 Building on previous OECD work, his report focuses on pension funds and insurance companies.

15 Other forms of institutional savings include foundations and endowment funds, non-pension fund money managed by banks, private investment partnership and other forms of institutional investors. Sovereign wealth funds are another type of institutional investor increasingly being approached to fund green investments (see Box 4).

16 Specifically, a project/technology that has obtained a high level of confidence from lenders and project developers and is at a suitably advanced stage of development to be ready to enter into commercial production.

17 This may not be the case in developing countries. 
estimated 25 year lifespan, with manufacturer warranties, long-term contracts with power purchasers and government support. ${ }^{19}$

In addition, as long-term investors, these institutions also have interest in themes such as climate change which can impact economic growth over the long run on which their investments depend. Indeed, there is growing concern amongst some institutional investors that the mainstream forecasts of the economic impact of climate change for the coming decades, have failed to properly take account of the significant tail risks associated with extreme climate change and as a result these greatly underestimate the possible economic risks involved. ${ }^{20}$ For example, the OECD 'Environmental Outlook to 2050' (OECD 2012) predicts that the cost of starting today to limit GHG concentrations to $450 \mathrm{ppm}$ using carbon pricing to meet the $2^{\circ} \mathrm{C}$ goal would be to slow economic growth by $0.2 \%$ a year on average, or $5.5 \%$ of global GDP in 2050. However, the cost of inaction could be as high as a $14 \%$ permanent loss of global GDP (Stern, 2007). Institutional pension funds have liabilities that stretch will into the second half of this century, so it has been argued that they have a direct interest in ensuring that investment in a low-carbon infrastructure takes place. ${ }^{21}$

\section{Box 1. How much is available for long-term investment?}

Although the total assets under management (AUM) number for institutional investors of USD 71 trillion is impressive, and growing, it should not be assumed that all of this capital is available for investment in long-term projects, such as clean technology.

The World Economic Forum (WEF 2011) estimates the size of capital from institutional investors as being significantly lower than the USD 71 trillion total. To start with, they narrow the definition of institutional investors which have the capacity to invest for the long-term down to USD 27 trillion - coming mostly from life insurance companies and defined benefit pension funds, but also sovereign wealth funds, endowments, foundations and family offices. The OECD see this number as potentially higher as defined contribution pension funds (representing $60 \%$ of the USD 28 trillion of total global pension assets) ${ }^{22}$ are also seen as having the ability to invest over the long-term (as evidenced by defined contribution style funds in regions such as Latin America and Australia investing in infrastructure projects).

The WEF then reduce this USD 27 trillion further to USD 15 trillion according to liability constraints (i.e. requirements to fund obligations in the near term which thus cannot have an indefinite horizon). Insurers and pension funds have largely a well defined set of liabilities, some of which have to be met in short-term time periods, which ultimately lead their investment decisions.

The WEF then reduce this total again according to what they term the impact of risk appetite, taking account of funding ratios, capital requirements and mark-to-market accounting as well as softer decision-making constraints such

18 Although Power Purchase Agreement (PPA) contract structures vary on a market-by-market basis, in various geographies renewable electricity tariff agreements include protection against inflation. For example, several tariffs in the EU are indexed to inflation and adjusted on an annual basis. In the UK retail price index (which includes the price of electricity in its basket) indexation exists on the renewable obligation certificate (ROC) system (onshore wind farms receive 1 certificate, offshore 2) - though this is likely to be grandfathered into a new structure (feed-in tariff with a contract for difference FiT CfD). In projects where specific inflation protection is not provided, high current cash flows provide a certain level of inflation protection. Finally, the assets provide a hedge to energy inflation as they have long useful lives and potentially benefit from scarcity value in the future (i.e. fewer desirable wind/solar sites).

19 Source: Blackrock (interviews).

20 See Mackenzie, Craig 'Unburnable carbon’ Financial Advisor (April, 2012) and (Weitzman, 2011).

21 See UNPRI Investor Leadership on Climate Change (2008) http://www.unpri.org/files/climate.pdf

22 This USD 28 trillion includes the USD 19 trillion of autonomous pension assets shown in Figure 2 as well as other types of pension fund, such as pension insurance contracts. 
as principal-agent concerns, on the ability to make and hold long-term investments. This results in a further reducing of USD 5.5 trillion - leaving USD 6.5 trillion available for long-term investors to employ.

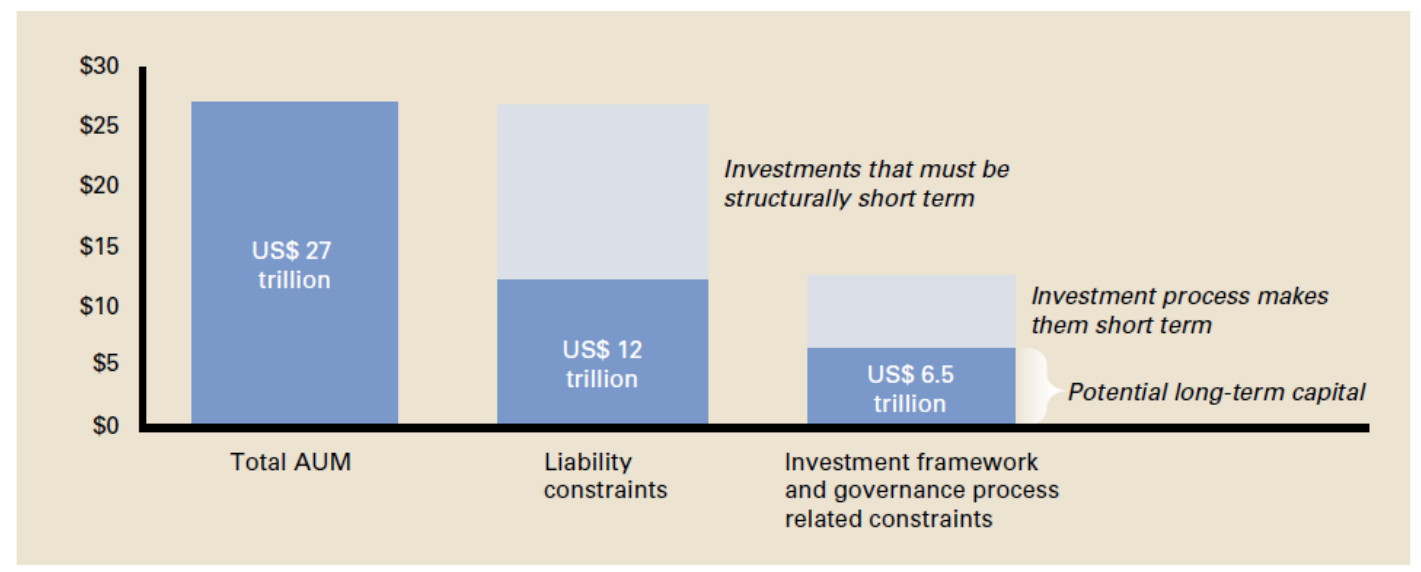

Note: Numbers are estimates.

Source: Celent, NACUBO, The Foundation Center, SWF Institute, OECD, US Federal Reserve Flow of Funds, CEA, Oliver Wyman analysis

It should also be noted that asset allocations change gradually and therefore the shift of this potential long-term capital into infrastructure assets such as clean technology projects will take time. Cash flows into pension funds in terms of new contributions (which the OECD estimates at around USD 960 billion annually) and premium income from annuity and life insurance contracts (estimated at USD 1,843 billion annually) could provide a more immediate source of funds.

\section{What are Institutional Investors' Current Allocations to Clean Energy?}

Private capital has started to flow into clean energy investments. Indeed in December 2011, Bloomberg New Energy Finance (BNEF) recorded the trillionth dollar of investment in renewable energy, energy efficiency and smart energy technologies since its records started in 2004 (BNEF, 2012). The OECD estimates that USD 70-119 billion per year is already flowing as international North-South climate finance today (to both mitigation and adaptation), with over half coming from the private sector. ${ }^{23}$

OECD analysis also shows that some CEM countries $^{24}$ (Figure 3 in red) have managed to attract the required investment to lower emissions in the power and industry sectors. For example, Denmark can be seen to have reduced its GHG emissions by $25 \%$ whilst increasing gross fixed capital formation by $50 \%$ in a broad category that includes investment in energy machinery and equipment. ${ }^{25}$ Increased capital investment with falling emissions is indicative of green growth.

23 OECD 2012c "Tracking Climate Finance: What and How?"; this report drawing on recent OECD data and CPI 2011 (see below). See http://www.oecd.org/env/cc/financing and http://www.oecd.org/dac/stats/rioconventions

24 The 23 governments participating in the Clean Energy Ministerial are: Australia, Brazil, Canada, China, Denmark, the European Commission, Finland, France, Germany, India, Indonesia, Italy, Japan, Korea, Mexico, Norway, Russia, South Africa, Spain, Sweden, the United Arab Emirates, the United Kingdom, and the United States.

25 Just under $40 \%$ of the OECD countries analysed achieved (absolute) green growth in the Power \& Industry sector during 1997 to 2007. All of the 25 countries assessed experienced growth in capital formation in 'Other machinery and equipment, category, but only 9 did so with a reduction in GHG emissions. The 9 nations achieving green growth in this sector included both western and eastern European countries. 
Figure 3. Change in Gross Fixed Capital Formation vs. Reduction in Green House Gases for Energy and Industry sectors, 1997-2007 (OECD countries and CEM Countries in RED)

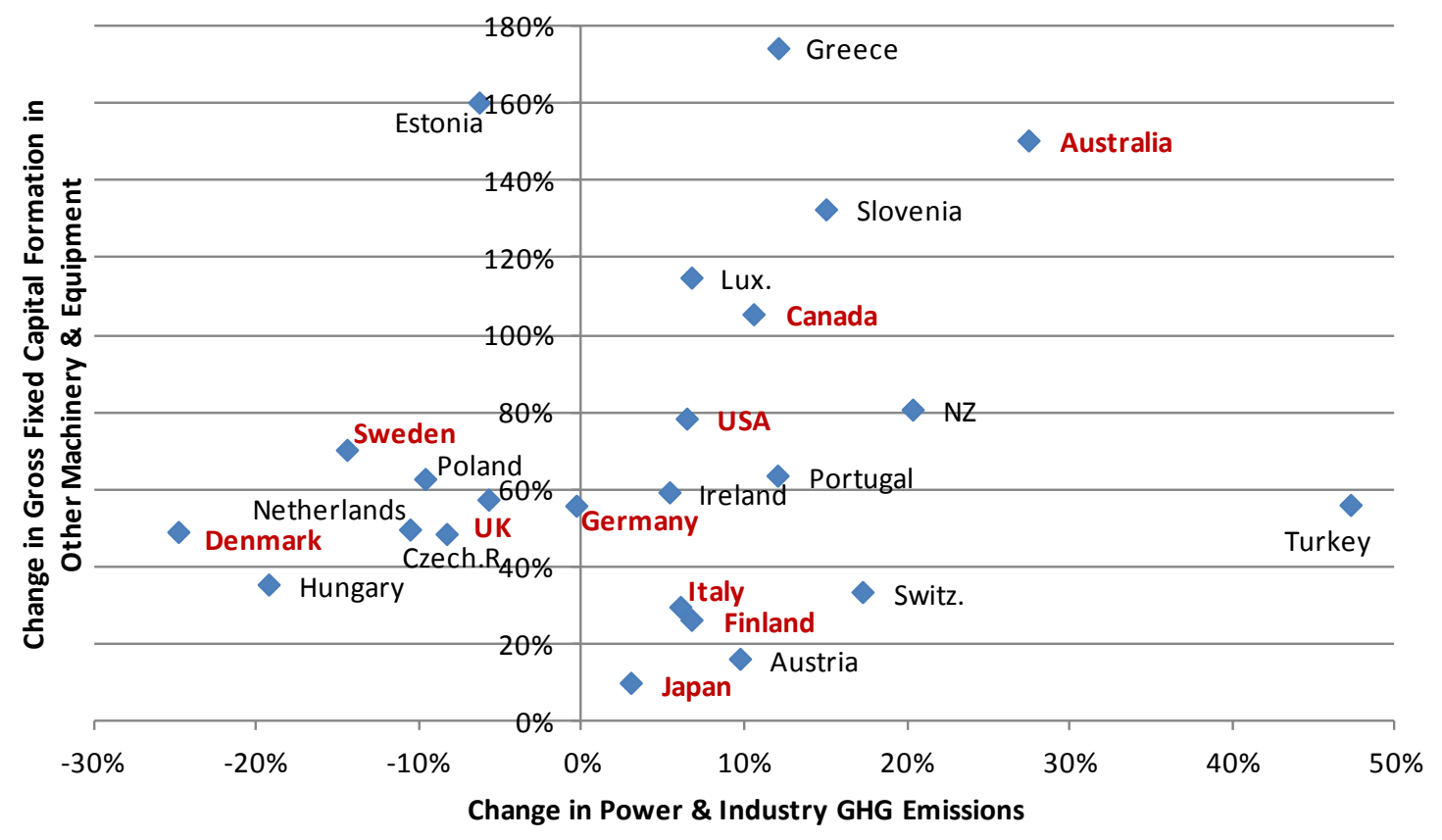

Source: (OECD 2012d forthcoming - Kennedy) $)^{26}$

However, only a limited amount of these funds are coming from institutional investors. The OECD estimates that less than $1 \%$ of pension funds' assets globally are allocated directly to infrastructure investment, let alone to clean energy projects. ${ }^{27}$ Likewise, insurance companies' direct allocations to infrastructure projects remain in the billions of dollars, compared with total industry assets of around $\$ 19.3$ trillion. By way of example, the Association of British Insurers (ABI 2011), representing the third largest insurance industry in the world (after the USA and Japan) notes that of the GBP 1.6 trillion in assets under management held by its members from their long-term savings products (i.e. pensions, annuities and lifeinsurance) most is invested in domestic and overseas equity and bonds. Other investment and cash accounts for $7 \%$ or around GBP 100 billion. Industry estimates are that up to around GBP 20 billion of this is invested in infrastructure, and it could be estimated that maybe 10\%, or around GBP 2 billion is in 'green' projects (mostly renewable energy such as wind farms and solar).

26 Figure shows percent changes from 1997 to 2007 in 3-year averaged gross fixed capital formation for 'other machinery and equipment' (calculated using national currencies with constant prices) and 3-year averaged GHG emissions summed for energy industries, manufacturing industries and construction and industrial processes (aggregate emissions in $\mathrm{CO}_{2}$ equivalents). Data on capital formation is from OECD Statistics; data on GHG emissions is for Annex 1 countries from UNFCCC. One outlier omitted from graph: Iceland increased gross capital investment by $85 \%$, while increasing GHG emissions by $89 \%$.

27 Excluding indirect investment in infrastructure via the equity and debt of listed utility companies and infrastructure companies. See (OECD 2011c), 'Pension Funds Investment in Infrastructure: A Survey' 
Defining and measuring 'green investing' is no simple task, and it can be difficult for policy makers to establish the extent to which institutional investors are currently funding new-build, low carbon technology projects and what role they may play to fill the funding gap in future. ${ }^{28}$

The main exposure of institutional investors to clean energy projects has so far been via holdings of the debt and equity of listed utility companies. Indeed, the primary source of capital for investment in low carbon power generation to date is the balance sheets of the electric power utilities and developers. However, the scope for this source of funding to grow is constrained by the willingness of institutional investors to purchase new debt and equity issued from the utility companies, which in turn depends on the state of their balance sheets and their consequent credit rating. ${ }^{29}$

Institutional investors may also be increasing their exposure to clean energy and other 'green' assets by adopting an SRI (socially responsible investing) or ESG (environmental, social and governance) investment approach. It is important to note that green investment has been traditionally mostly embedded in a broader approach. In fact, the investment volumes in ESG / SRI assets are a multiple of those in 'pure' green investments. For example, some estimates see SRI assets as high as EUR 7 trillion (two-thirds in Europe) ${ }^{30}$ but this would include screening of stocks on 'relative' rather than absolute 'green' definitions, and therefore drawing the definition very wide. When 'green investing' comes through the door of SRI or ESG, it may not be particularly focused on green or climate change investments as SRI/ESG is most popular as an 'overlay' process to standard investment policies without targeting particular green assets. On the other hand, by working with an ESG policy, investors may become more sensitive towards green issues and be inclined to dedicate more capital to climate change-related assets in the future, and do so more quickly.

The key to knowing how much finance from institutional investors is really reaching clean energy and to estimating the financing gap is tracking the capital that institutional investors can provide via direct investment in these projects. These investments are typically made through financing vehicles such as green bonds or private equity-style investments (shown as the unlisted or 'over the counter' (OTC) sections marked in red in Figure 4). Yet outside the largest pension funds and insurance companies, asset allocation by institutional investors into the types of direct investment that can help close the clean energy financing gap remains very limited. Barclays (2011) estimates that of the capital required to fund low carbon infrastructure up to 2020, EUR 2.2 trillion $^{31}$ will need to be financed by sources such as institutional investors external to the entity procuring or developing the project. How to stimulate these direct investments by institutional investors is the focus of this report.

28 For an in-depth discussion of the topic see (OECD 2012b forthcoming) 'Defining and Measuring Institutional Investors' Allocations to Green Investments'.

29 The scope for utility companies to expand their balance sheets to increase the capacity of investment in the clean energy field is constrained by the willingness of institutional investors to purchase new debt and equity issued from the utility companies. This willingness depends on fundamental considerations about the risk-return characteristics of new energy infrastructure, as well as appetite for credit risk reflected in a utility's credit ratings. If a utility company increases leverage by issuing new bonds, this may increase the ratio of debt to equity and could weaken its credit rating, reducing the desirability of its debt to institutional investors. If a utility company wishes to issue new equity to fund extended development of renewables, investors will ask whether this will improve or dilute the quality of the company's earnings. Low risk, high return projects may justify further capital raising, higher risk projects (e.g. offshore wind) may not do so. If utility companies are to come to the market asking for large scale new financing for renewable energy projects, the projects will have to offer investors the prospect of enhanced risk-adjusted returns.

30 Eurosif (OECD 2012b - forthcoming).

31 In Europe (EU 25), China, India, USA, Japan, Canada and Australia. 
1. Asset allocation by institutional investors into the types of direct investment which can help close the clean energy financing gap remain limited. Indeed the green bond market and clean technology private equity industry as a whole are each estimated as constituting only some hundreds of billions (OECD, $2012 b$ - forthcoming).

Figure 4. Main Institutional Investors' Financing Vehicles for Infrastructure Investment

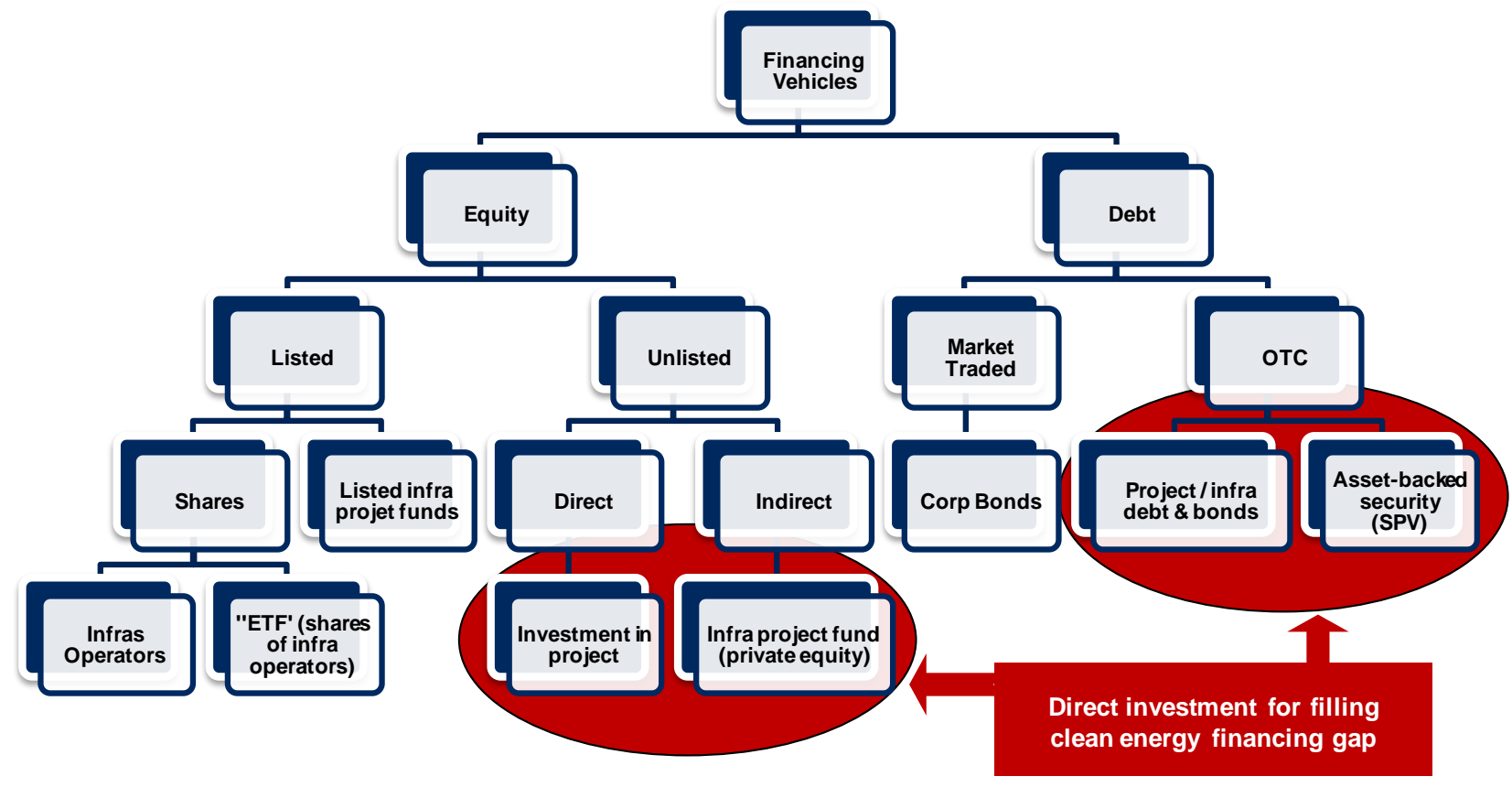

Source: OECD analysis

That said, institutional investors interest in the clean energy sector is starting to develop, and has picked up since the financial crisis. ${ }^{32}$ They are slowly starting to be attracted to climate change-related financial products which help finance projects with a positive environmental impact while remaining appealing from a financial return perspective. Institutional investors have already formed groups to represent their interests (see Table 1) with the 2011 Global Investor Statement on Climate Change supported by 285 investors representing assets of more than USD 20 trillion. ${ }^{33}$ Signatories to the United Nations Principles of Responsible Investment (UNPRI) have now grown to more than 850 institutional investors with US\$25 trillion under management - a signal that they are beginning to recognize the connections between a commitment to incorporate ESG issues into their policies and practices and the fundamental fiduciary duties of loyalty and impartiality. ${ }^{34}$ Though there is still a discussion around what 'fiduciary duty' implies in terms of responsible investing, it is now generally accepted as compatible provided investments are made on a financially compatible basis with non-green investment (given the fiduciary responsibility to achieve the primary financial task such as a maximising returns or producing a stable pension or life insurance for its participants).

32 See OECD(2011c), 'Pension Funds Investment in Infrastructure: A Survey'.

33 Available at http://www.ceres.org/files/press-files/2011-global-investor-statement-on-climate-change/official2011-global-investor-statement-on-climate-change

34 See (Hawley, Johnson and Waitzer 2011) 
Table 1. Institutional Investors Climate Change Groups

\begin{tabular}{|c|c|c|c|}
\hline Group & Type of Investors & $\begin{array}{l}\text { Size of total } \\
\text { AUM }\end{array}$ & Objectives \\
\hline IIGCC & $\begin{array}{l}75 \text { European institutional } \\
\text { investors, including major } \\
\text { pension funds }\end{array}$ & $\begin{array}{l}\text { EUR } 7.5 \\
\text { trillion }\end{array}$ & $\begin{array}{l}\text { Catalyse greater investment in low carbon } \\
\text { economy }\end{array}$ \\
\hline $\begin{array}{l}\text { Investor Network } \\
\text { on Climate Risk } \\
\text { (managed by } \\
\text { Ceres) }\end{array}$ & 100 USA institutions & $\begin{array}{l}\text { USD } 10 \\
\text { trillion }\end{array}$ & $\begin{array}{l}\text { Identify opportunities and risks in climate } \\
\text { change, tackle the policy and governance } \\
\text { issues that impede investor progress towards } \\
\text { more sustainable capital markets }\end{array}$ \\
\hline $\begin{array}{l}\text { Investor Group on } \\
\text { Climate Change }\end{array}$ & $\begin{array}{l}\text { Australian and New Zealand } \\
\text { investors }\end{array}$ & $\begin{array}{l}\text { AUD } 700 \\
\text { billion }\end{array}$ & $\begin{array}{l}\text { Raise awareness, encourage best practice in } \\
\text { terms of analysis and provide information } \\
\text { relating to climate change }\end{array}$ \\
\hline $\begin{array}{l}\text { Asian Investor } \\
\text { Group on Climate } \\
\text { Change (AIGCC) }\end{array}$ & $\begin{array}{l}\text { Financial institutions from } \\
\text { across the region, including } \\
\text { prominent asset owners and } \\
\text { fund managers. }\end{array}$ & TBD & $\begin{array}{l}\text { To ensure there is a clear Asian investor } \\
\text { voice on climate change to understand the } \\
\text { issues as they affect the region and to } \\
\text { compliment the work of other investor } \\
\text { groups around the world (being established). }\end{array}$ \\
\hline $\begin{array}{l}\text { Long-term } \\
\text { Investors Club }\end{array}$ & $\begin{array}{l}14 \text { mainly public sector } \\
\text { financing institutions }\end{array}$ & $\begin{array}{l}\text { USD } 3 \\
\text { trillion }\end{array}$ & $\begin{array}{l}\text { Indentify long-term investment funds and } \\
\text { vehicles }\end{array}$ \\
\hline ClimateWise & $\begin{array}{l}40+\text { leading insurance } \\
\text { companies and related } \\
\text { organisations }\end{array}$ & $\begin{array}{l}\text { USD } 3 \\
\text { trillion }\end{array}$ & $\begin{array}{l}\text { Goals include leading risk analysis and } \\
\text { incorporating climate change into investment } \\
\text { strategies }\end{array}$ \\
\hline
\end{tabular}

Source: OECD; Authors' analysis (via organisation websites)

A recent OECD survey on infrastructure investment, asked pension funds to identify their involvement in green projects. ${ }^{35}$ Although 'green' investment is not specifically addressed in the investment policies of the pension funds surveyed, nor is a target allocation specified, some of the world's major pension funds have invested in clean energy projects. Some - such as ATP in Denmark- have set up their own clean energy fund and are inviting other pension funds to join them. Others, (such as APG in the Netherlands) make their own direct investments or are investing in clean energy funds run by third parties (for example another major Dutch fund, PPGM, has committed capital to BNP Paribas Clean Energy Fund). Some of the world's largest funds (including the pension plans for California's state teachers and public employees, CalSTERS and CalPERS) actively target clean energy projects via their ESG / SRI screenings and overlays as well as via direct investments.

According to the BNEF database, pension funds have invested in around 50 private equity funds that raised an estimated USD 21 billion in total ${ }^{36}$ between 2002-2010 (BNEF, 2012). The exact amount of pension fund commitments are not known and are not disclosed by the database but are likely much lower. In addition, at least 27 asset financing transactions of bond, balance sheet and convertible/term loans (valued at approximately USD 12 billion in aggregate between 2004-2011) and at least 12 Venture Capital

35 OECD Largest Pension Funds Survey 2011, based on 27 pension funds representing USD1.6 trillion of assets under management. (See OECD 2012e forthcoming - Largest Pension Funds 2011 Survey).

36 Exact pension fund commitments are not known / disclosed. 
and Private Equity deals (valued at USD 9 billion in aggregate between 2002-2011) involved pension funds although how much of this was pension fund capital is not known and is likely much smaller than the total. In 2011 Pension Funds (notably PensionDanmark, see Box 2) directly invested USD 4 billion in offshore wind energy through a combination of balance sheet financing (USD 1.6 billion) and construction convertible/term loans (USD 2.4 billion).

Figure 5. Clean energy asset financing where pension funds have been involved (USD Millions, 2004-2011)

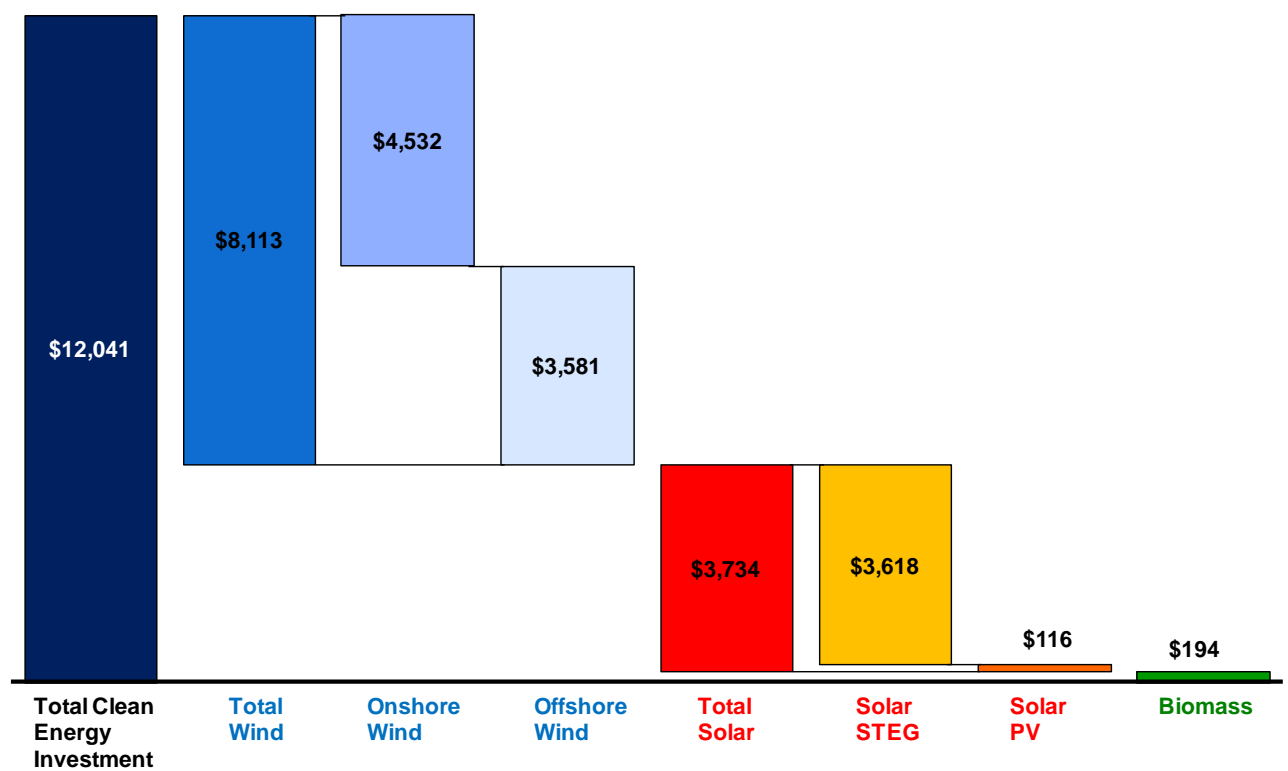

Source: OECD; Author's analysis based on BNEF database 


\section{Box 2. Examples of Pension Funds' Investments in Clean Energy Projects}

APG: APG carries out collective pension schemes in Holland for beneficiaries in the education, government and construction sectors, cleaning and window-cleaning companies, housing corporations and energy and utility companies. APG invests the pension assets of more than 4.5 million Dutch people with total invested assets of around EUR 300 billion (March 2012). Actively trying to source attractive investments that promote solutions to sustainability issues, APG invests, for example, in alternative energy, clean technologies and micro-credits. APG has invested EUR 5 billion in renewable energy (solar, wind, biofuels, etc.) environmental technology (water, waste, rail, energy efficiency, etc), sustainable timber, microfinance and social infrastructure (hospitals, elderly homes and schools) through infrastructure funds, co-investments, hedge funds, private equity and listed equity. Furthermore, improving energy efficiency in the Real Estate sector is one of APG's focus areas. APG is a driving force behind the Global Real Estate Survey Benchmark (GRESB) which makes it possible to assess and benchmark the sustainability performance of real estate portfolios. EUR 3.5 billion of APG's Real Estate funds are invested in so-called Green Stars with a high GRESB score; these have reduced their energy use by $3 \%$ in 2011 compared to 2010, whereas the average reduction was only $1 \%$.

$\boldsymbol{A T P}$ : the Danish pension fund covering most of the population, has invested in renewable energy infrastructure and technology, such as solar wind and hydro, as well as biofuels and biomass for a long time. ATP invested DK 600 million in renewable and has committed DK 2.2 million to concrete assets and over DK 2 billion of equity in companies that are related to the renewable and clean energy sector. At the COP-15 summit in December 2009, ATP pledged $€ 1$ billion to a new climate change fund for investing in emerging economies, with an open invitation to other European investors to join it. The new fund (run as a specialist entity within ATP with its own management) will invest in existing growth structures, aid programmes and funds in emerging economies that are overseen by the UN, World Bank and regional development banks. ATP announced that its first investment (directly into a renewable energy project) in the first quarter of 2011.

BT Pension Scheme (BTPS): the largest corporate defined-benefit scheme in the UK is known for its leading stance on sustainable investment. For example, BTPS and the UK Government seeded the Hermes GPE Environmental Innovation Fund with GBP 75 million and GBP 50 million respectively with the aim of investing in UK-based, lowcarbon and clean technology funds and to co-invest in companies which improve resource efficiency.

CalPERS: The California Public Employees' Retirement System (CalPERS) is the largest public pension system in the United States with a total fund market value of approximately USD 237 billion. CalPERS has a long standing commitment to ES issues with a broad range of innovative activity in the field. In 2011, the CalPERS Board Investment Committee approved the adoption of a total fund process for integrating ESG issues as a strategic priority. The purpose of this initiative is to integrate ESG factors into decision-making and investment processes across the total fund in order to enhance risk management and capture opportunities in a consistent manner. In addition, one of the ways in which CalPERS makes an impact on climate change is by providing capital through private equity funds for innovative firms that create more efficient and less polluting technologies than current products. As of September 30, 2011, CalPERS Alternative Investment Management (AIM) program has approximately $\$ 1.2$ billion of aggregate exposure to the alternative energy sector with a particular emphasis on solar power and biofuels, including:

- \$200 million to clean technology investments through our AIM Environmental Technology Program (Phase I) established in 2005;

- an additional \$480 million through Phase II, the CalPERS Clean Energy and Technology Fund;

- and partnership commitments to clean energy and technology of more than $\$ 500$ million.

In 2004, the CalPERS Investment Committee established a goal of reducing energy consumption of the underlying assets in its Core Real Estate portfolio by 20 percent by 2009 . At the end of this five-year program, the investment managers exceeded this target, reporting a total energy reduction of 22.8 percent. CalPERS also has a long-standing investment in forestlands.

CalSTERS: the Private Equity Clean Technology and Energy Program has commitments in excess of USD 600 million and is a diversified portfolio of venture and buyout investments across the clean technology and clean energy universe. The program is global in nature and encompasses both fund investments and co-investments. In addition, CalSTERS Global Equity investments include a sustainable manger portfolio with a 'double bottom line' legal of financial and sustainable outperformance, and CalSTERS Fixed Income Green Program screens and monitors fixed income holdings both in terms of ESG risk exposure and ESG opportunity capture.

PensionDanmark AS: one of the country's largest pension funds with a rapidly growing balance sheet currently with USD 23 billion under management. Torben Möger Pedersen, its CEO, explained at the 2012 Bloomberg New Energy 
Finance Conference how his fund aims to allocate 10\% AUM into long term holdings of direct infrastructure and renewable assets, and is already well on the way with USD 1.5 billion in a portfolio of solar and offshore wind (including both the Nysted and Anholt Offshore Wind farms). Projects in the sector are offering attractive returns, at a lower risk than listed equity markets, he said. Pedersen sees a number of European, Canadian and Australian pension funds active in the same space with good opportunities for cooperation. The fund is also working with EKF, Denmark's export credit agency to provide long-term financing of export credits to allow foreign enterprises to obtain loans to place renewable energy orders with Danish companies.

PGGM: currently administer some EUR 100 billion of pension assets for five Dutch pension funds, including Stichting Pensioenfonds Zorg en Welzijn ("PFZW"), the second largest pension fund in the Netherlands covering workers in the health sector. PGGM is especially interested in renewable energy opportunities and has already invested in wind farms. In 2009 PGGM committed capital to the BNP Paribas Clean Energy Fund on behalf of its clients. PGGM also manage a EUR 100 million interest in the Ampere fund on behalf of its clients. The second fund is from $\mathrm{Hg}$ Renewable Power Partners, in which PGGM has also invested EUR 50 million on behalf of one of its clients. As of the end of $2010,9 \%$ of the infrastructure portfolio was invested in sustainable energy (amounting to $17.5 \%$ of committed capital).

Some of the major insurance companies around the world have also made commitments to lowcarbon investment, and indeed have signalled their commitment to the sector through the development of a set of Principles for Responsible Insurance. ${ }^{37}$

However, when assessing insurance companies' exposure to green investments it should be noted that this comes in several forms. Unlike pension funds which are asset owners, in addition to their own assets arising from their life insurance and annuity business, insurance companies are also asset managers, investing money for external clients as well as their own parent insurance company funds. This makes it difficult to get a holistic view of how much in terms of green assets an insurance company is in total exposed to.

That said, some of the world's leading insurance companies are making important commitments to clean energy. OECD analysis using the BNEF database determines that insurance companies have taken part in around USD 10.8bn of clean energy asset financing to date. BNEF (BNEF, 2012) notes that insurance companies participated in 15 funds which raised a total of USD 5.1 billion from 2001 to 2010. In addition, insurance companies provided asset financing in balance sheet funding and convertible/term loans in at least 29 transactions (valued at approximately USD 10.8 billion between 2004 and 2011). Again, these are aggregate numbers and the total amount of insurance company commitments are likely much lower than the total.

37 These are being developed by the Insurance Commission of the United Nations Financing Initiative (UN FI) which promotes the Principles for Responsible Investing (UN PRI). The four principles include integrating ESG issues into insurance business lines and promoting ESG across the insurance industry. The Principles will be launched at the UN Conference for Sustainable Development to be held in Rio de Janeiro in June 2012. See Responsible Investor, $1^{\text {st }}$ December 2011, 'World's largest insurers meet next week to finalise ESG-based Principles for Sustainable Insurance'. 
Figure 6. Clean energy asset financing where insurance companies have been involved (USD Millions, 2004-2011)

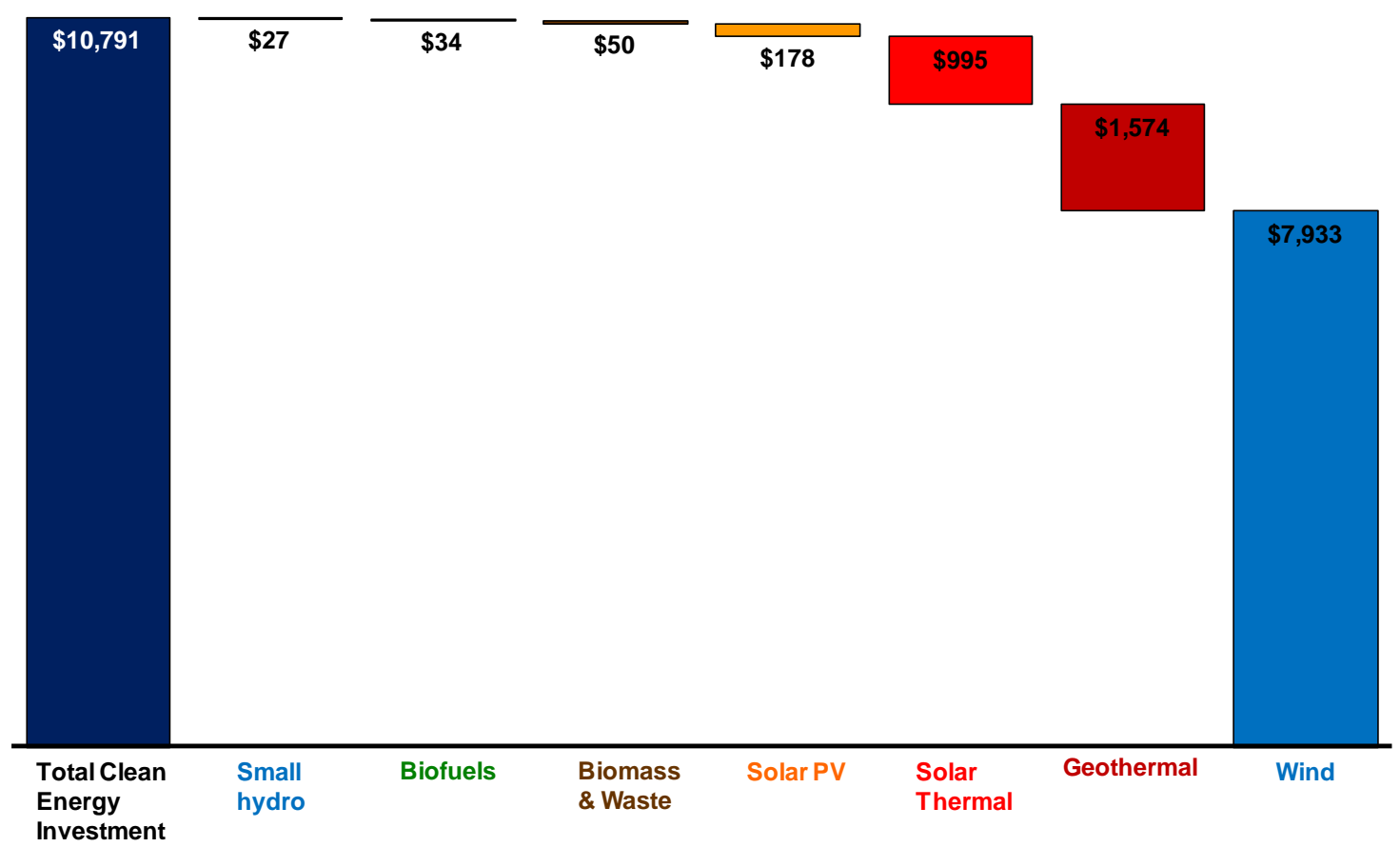

Source: OECD; Author's analysis based on BNEF database 


\section{Box 3. Examples of Insurance Companies' Investments in Clean Energy Projects}

Allianz: The German insurer aims to invest up to EUR 1.5 billion in renewable energy projects by 2012. As of March 2012 it has invested a total of EUR 1.3 billion in renewable energies, after buying three additional wind farms. Two of those are newly-built Nordex sites in France, which deliver around 22 megawatts, and one is in Germany with a capacity of 16 megawatts. At the start of 2011, Allianz's investments in wind and solar energy surpassed the EUR1 billion mark, and the company increased that amount by nearly $25 \%$ in the past 12 months. In total, Allianz now owns 34 wind farms with a total capacity of 658 megawatts and seven solar parks with a total capacity of 74 megawatts.

Aviva: The UK insurance company has exposure to green investment via several sources. First the parent insurance company (using its life insurance and annuities assets) has committed $1.5 \%$ of its assets to infrastructure investment. As well as gaining exposure to green assets via the Clean Tech fund, the company also invests directly in clean energy projects via its private equity investments. Aviva Investors, the asset management subsidiary of the parent insurance company, runs a European Renewable Energy fund of around EUR 250 million, investing in solar, biomass, biogas and wind projects. Returns are targeted at $12 \%$ IRR with yields of $10 \%$. The vehicle is Luxembourg regulated and specialized investment fund, structured as a SICAV and available to institutional investors. Money in this fund comes from both the parent insurance company's life insurance and annuities business, as well as from external clients (mostly pension funds). The fund will invest predominantly in greenfield projects but will also consider brownfield and secondary stage established assets.

Manulife (John Hancock): The company has an investment team dedicated to energy investing, including renewable projects. Hancock/Manulife's USD 3 billion renewable energy portfolio in the US includes wind, geothermal, biomass, solar, hydro, and energy efficiency investments. Over a four year period, John Hancock and its parent company, Manulife Financial, have invested billions of dollars in renewable power projects including wind, hydroelectric, geothermal, biomass, landfill gas and solar plants across the U.S. and Canada. For example, the company provided a USD 55 million loan that financed the construction of a 14MW solar plant on U.S. Air Force Base in Nellis, Nevada. In another instance, the company provided a USD 120 million loan to the U.S. Department of Energy for the construction of 20MW biomass facility in Savannah River, South Carolina that would replace an existing coal-fired plant.

MetLife: the US insurer has invested more than USD 2.2 billion in clean energy, and recently announced that it purchased a stake in Texas's largest photovoltaic project (a 30-megawatt plant with a contract to sell the output to Austin's municipal utility for 25 years). ${ }^{38}$

Munich Re: has announced plans to invest about EUR 2.5 billion in the next few years in renewable energy assets such as wind farms, solar projects and new electricity grids. ${ }^{39}$

Prudential: Prudential and its UK and European fund management arm, M\&G investments, have been investing in infrastructure for more than 80 years. One of the Prudential's first infrastructure investments was financing the hydroelectric dam in Scotland in the 1930's (Carsfad Dam). Today Prudential is one of the leading managers of infrastructure assets through holdings in private debt and equity, as well as through corporate bonds and public equity investments. Infracapital is M\&G's infrastructure investment arm. Among its investments are solar and wind power projects and it is currently raising institutional capital for a third infrastructure investment fund.

Insurance companies also have significant exposures to climate change on the liability side of their balance sheets (chiefly via insurance claims resulting from flood, windstorm and other catastrophic perils). This makes them uniquely placed to assess and understand the risks of climate change. As well as being

38 See Bloomberg News 21/3/2012 'Solar 15\% Returns Lure Investments from Google to Buffett'.

39 According to an Associated Press report. AP cited Robert Pottmann, who is Head of Renewable Energy \& New Technologies (RENT) at Munich Ergo AssetManagement GmbH, Munich Re's asset management arm, in a wider report on German renewables. 
institutional investors themselves, insurance companies also have a role to play in terms of providing risk mitigation tools (as discussed in the later section of this report), which will be key in terms of mobilising capital from other sources.

Though some major insurance companies have made commitments to clean energy, regulation may be hampering their exposure to this space (see later section). In addition, it may be harder for insurance companies to collaborate in terms of their investments, given that their asset manager role makes them direct competitors (unlike most pension funds). The potential for greater investment is there and investment from insurance companies does have the scope to increase, but the headline numbers and the potential should not be over estimated.

Another potential source of financing for clean energy projects is Sovereign Wealth Funds (SWF). These investors not only have a long-term horizon but also often have specific SRI objectives though mandates to address significant public policy issues that could affect the viability of their investments and intergenerational well-being, not least as many of the countries with SWF have significant exposure to climate-related risks through their ownership of hydrocarbon resources (see Bolton et al. 2012).

Although SWFs have less available capital compared to other institutional investors, with assets under management of approximately USD 5 trillion (SWF Institute), they are increasingly being approached for funding green ventures. With SWFs' assets expected to at least double within the next decade, ${ }^{40}$ and growing awareness of their economic impact and capacity to project state political power, international efforts to create voluntary behavioural codes for such funds have grown. The principal achievement to date is the Santiago Principles, ${ }^{41}$ which emphasise transparency, clarity, and equivalent treatment with private funds similarly operated. In addition to these issues, the socially conscious goals of some SWFs has stirred debate about the wisdom of mixing ethical investment with wealth maximisation goals, and attempting to influence corporate social and environmental behaviour. ${ }^{42}$

This debate continues as SWFs begin to scale up investments in natural resources, energy, and global infrastructure. Current market activity indicates that, with the growing involvement of SWFs, multiple green funds are indeed forming. Clearly, SWFs are positing themselves to play a significant role in financing the green economy through a diverse range of investment vehicles (Box 4).

$40 \quad$ International Monetary Fund, “Norway's Oil Fund Shows the Way for Wealth Funds,” IMF Survey Magazine: Policy (9 July 2008).

41 International Working Group of Sovereign Wealth Funds, Sovereign Wealth Funds, Generally Accepted Principles and Practices: Santiago Principles (October 2008), available at http://www.iwgswf.org/pubs/gapplist.htm.

42 See Benjamin, J. Richardson (2011), Sovereign Wealth Funds and the Quest for Sustainability: Insights from Norway and New Zealand, University of British Columbia - Faculty of Law 


\section{Box 4. Examples of Sovereign Wealth Funds' Investments in Clean Energy Projects}

Abu Dhabi (UAE): Masdar Capital is funded by the UAE's Sovereign Wealth Fund Mubadala and seeks to build a portfolio of renewable energy and clean technology companies. It helps its portfolio companies grow and scale-up by providing capital and management expertise. Masdar Capital targets investments that have the greatest potential globally and to the UAE and is particularly focused on the following sectors:

- Clean energy: including power generation and storage technologies, transportation technologies, clean tech/clean energy innovation, and sustainable biofuels.

- Environmental resources: including water and waste management, and sustainable agriculture technologies.

- Energy and material efficiency: including developments in advanced materials, building and power-grid efficiency, and the enabling technologies.

- Environmental services: including environmental protection and business services.

Investment in these markets is made via two funds:

- Masdar Clean Technology Fund (MCTF): launched in 2006 MCTF, a fully deployed USD 250 million fund invested USD 45 million in three clean tech funds and the remaining USD 205 million in 12 direct investments in companies, as lead or co-lead investor. It was launched in conjunction with partners Consensus Business Group, Credit Suisse and Siemens AG.

- DB Masdar Clean Tech Fund (DBMCTF): launched in 2009, DBMCTF, is jointly managed with Deutsche Bank and raised US\$290 million in its final close, has an initial investor group led by Siemens and includes the Japan Bank for International Cooperation, Japan Oil Development Co. Ltd., Nippon Oil Corporation, Development Bank of Japan, GE, and Mitsubishi Heavy Industries. Both funds follow an active management investment strategy. The targeted investment amount is between US\$15-35 million and seeks to realize strong risk-adjusted returns, particularly through investments in mature technologies. The investment horizon is between 3 and 5 years.

Through these funds, Masdar Capital also seeks to demonstrate, commercialize and promote renewable technologies in the UAE, and to identify synergies between its investments and other Masdar activities, as well as the long-term energy and development program of the UAE. Mubadala is involved in all aspects of the clean energy value chain.

In addition to the operations under Masdar Capital, a separate subsidiary, Masdar Power, invests directly in energy projects. For example, Shams One is a 100MW CSP plant in Abu Dhabi that Masdar Power did in conjunction with Total and Abengoa. Masdar Power also took a 20\% stake in the London Array offshore wind project, where it is responsible for 630MW during Phase 1.

In addition to the current Masdar funds, Masdar and the Development Bank of Japan have recently formed a special high-level project fund that aims to purchase solar and wind plants in developed countries. The two governmentcontrolled entities will hold an equal share in the platform and will target pension funds as potential investors. This is notable since it is an example of a doubled-up institutional investor initiative, where a SWF uses its capital to attract and then co-invest with global pension fund capital.

China: China Investment Corporation (CIC) is also investing heavily in green growth. For example, recently CIC has invested in wind (USD 1.6 billion in AES and USD 60 million in Huaneng Renewables) and solar (USD 709.7 million in GCL). CIC recently agreed to purchase a minority stake in the asset manager EIG Global Energy Partners.

Kuwait: The National Technology Enterprises Company (NTEC), a fully own subsidiary of the Kuwait Investment Authority (KIA), took an 11\% stake in Heliocentris Energy Solutions in May 2011. Heliocentris aims to replace diesel generators with "zero-emission" products, such as fuel cells. 
Malaysia: Khazanah is the strategic investment fund of the Government of Malaysia (AUM M\$108 billion). 14\% of the fund is invested in property, $10 \%$ in utilities, and $10 \%$ in infrastructure. The strategy unit is currently undertaking a study on sustainable investing, looking for opportunities associated with climate change. The fund currently invests in the "carbon space" including in clean energy projects. For example, Khazanah will invest USD 150 million over three years in a venture to develop at least eight municipal waste-to-energy projects in China with Beijing China Sciences General Energy \& Environment Co (2009 saw the first rollout of a municipal waste-to-energy plant in the city of Tai'an in Shandong Province, China). In addition, Khazanah acquired a $23.59 \%$ stake in Camco International Ltd (Camco), a leading global developer of emission reduction and clean energy projects, with operations in the USA, UK, China, Russia and SEA, which is listed on the AIM of the London Stock Exchange. Concurrently, in December 2010, Khazanah and Camco established a Joint Venture company, Camco South East Asia (Camco SEA), to be headquartered in Kuala Lumpur, which will focus on investments in emission to energy projects, carbon credit development and advisory services, with the goal of establishing a business platform that can quickly realise and implement Clean Development Mechanism (CDM) projects in Malaysia and throughout South East Asia.

Norway: Norway's sovereign wealth fund is the largest in Europe, and second largest in the world. The for USD 611 billion fund (SWF institute 2012) formerly called The Government Petroleum Fund, was renamed the Government Pension Fund - Global (GPF-G) in 2006 to better reflect its intended use: providing security for future generation Norwegians. It refined its legislative mandates to invest ethically in 2010 and has invested USD 3.1 billion in cleantech companies in emerging economies like China, India and Brazil and has been an investor in the World Bank's Green Bonds. At home large investments are being made in off-shore wind farm development to make use of the country's extensive shore line. In 2010, the Norwegian Ministry of Finance initiated a complementary programme for active environmental-related investment, focusing on firms pioneering climate-friendly energy efficiency, carbon capture and storage, water technology, and waste and pollution management. The programme is worth about NOK 20 billion (equivalent to less than 1\% of the value of the NGPF-G portfolio) invested between 2010 and 2015.

Qatar: Feb 2012, Qatar Investment Authority increased its stake to 8.4 percent in Iberdrola SA, boosting its investment to USD 3 billion. Iberdrola is the world's biggest owner of wind farms and Spain's largest electricity provider.

Although beyond the scope of this report ${ }^{43}$, it is important to note that energy efficiency represents a significant largely untapped opportunity for meeting the dual goals of risk-adjusted financial return and environmental protection. Institutional investors are interested in energy efficiency in several ways. First, for the potential positive impact on the bottom line at the world's biggest companies in which they invest, since most of them have cost-effective opportunities to reduce their carbon emissions, but are not always good at exploiting them, for many reasons. Institutional investors have a role to play in driving change through the boardrooms for companies and unlocking this shareholder value opportunity. They are making their voices heard via the Carbon Disclosure Project Carbon Action Initiative ${ }^{44}$, which represents 92 pension funds, asset managers, insurers and banks, and makes annual requests to the largest, most carbon intensive companies in the world to take cost effective measures to improve their energy efficiency. This action is followed up via shareholder engagement with senior management in companies to challenge inaction and making the case for improvement.

In addition, innovative financing mechanisms are also being developed to allow institutional investors to directly access the financial returns available from energy efficiency projects (such as PACE Bonds and the UK - Green Deal Program). However, in practice there are limited opportunities for institutional investors in such projects. The roll-out of energy efficiency is often fragmented and unstructured, with many small-scale projects each requiring funding, rather than a small number of large-scale projects. Challenges expressed by the investors include the absence of aggregation mechanisms for energy efficiency investment in residential and commercial buildings, the limited experience with energy

43 OECD anticipates further work in this important area.

44 www.cdproject.net. 
efficiency funds so far, a lack of benchmarks and the fact that energy efficiency faces tough competition in-house from other investment opportunities. Energy efficiency can appear to be riskier than other investments when the security is based on energy savings rather than collateral in the form of assets (IEA, 2012 forthcoming). Energy efficiency bonds have considerable potential for sourcing capital from institutional investors, but they need to be investment-grade, which is currently a challenge. Finally, there is a need for models such as PACE to be used in the municipal and community space that can scale up adoption. 


\section{BARRIERS TO CLEAN ENERGY INVESTING}

Given the scale of capital pools in the hands of institutional investors and evidence of an emerging interest on their part for clean energy investments, policy makers need to ask what barriers may prevent them from significantly scaling up their investments in infrastructure? As figure 7 shows, institutional investors are currently only a minor source of financing even in developed countries (NB in developing economies the $2 / 3$ private, $1 / 3$ public split of infrastructure financing would switch around). Though they will never fully replace the other key financing sources, there is clearly scope for the role of institutional investors to increase.

Figure 7. Sources of infrastructure financing - Estmimate for Developed Economies

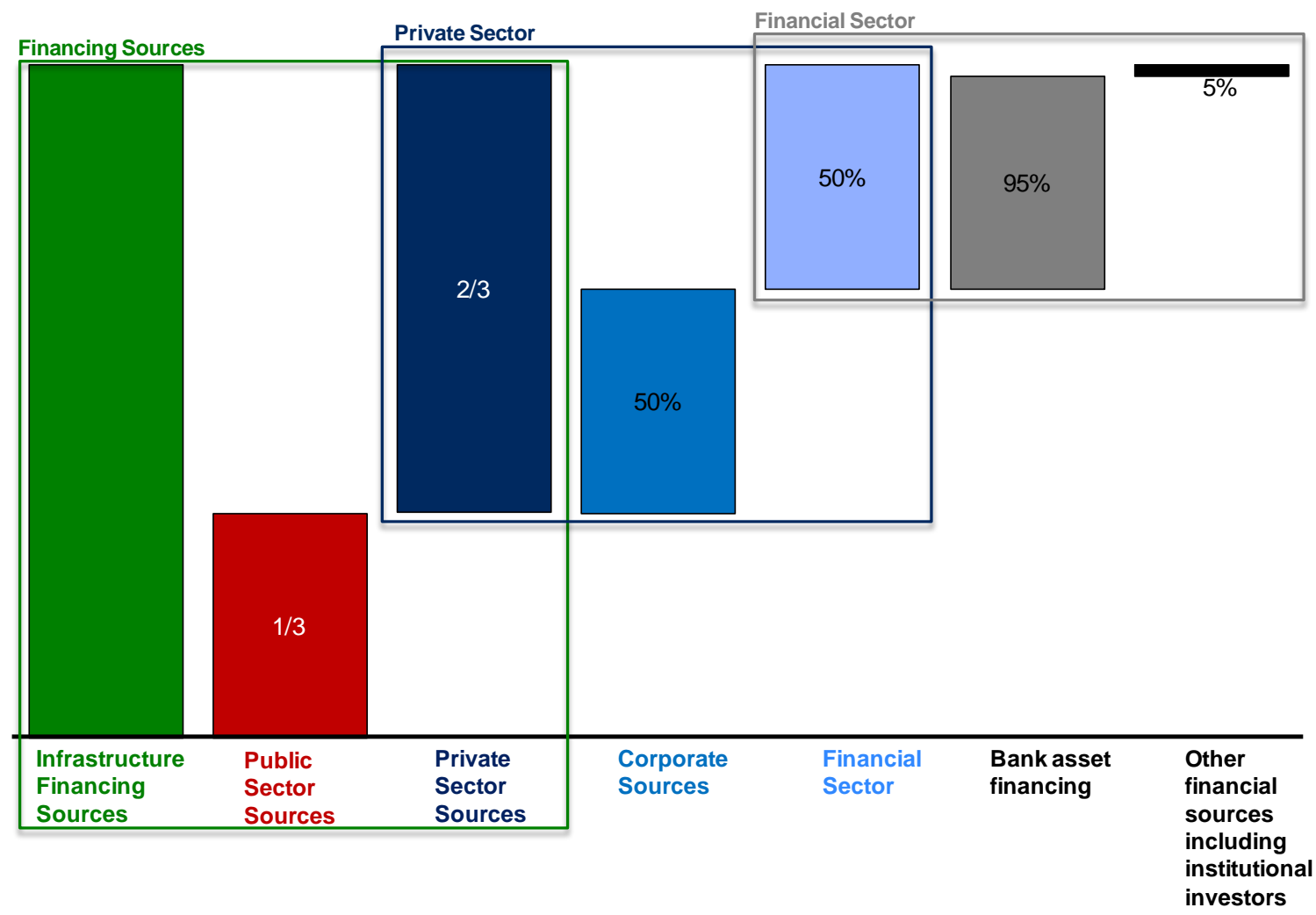

Source: OECD; Author's analysis based on EIB figures

\section{Problems with Infrastructure Investment}

It is important to stress that many barriers apply to direct investment into infrastructure-style projects more generally, whether or not the project is 'green'. Given that clean energy investments are generally a subset of infrastructure investments, one approach is to first consider why institutional investors have shown limited interest in this sector, before trying to understand their reservations towards green projects such as clean energy. These hurdles need to be overcome before investors will decide whether an investment is made in new cleaner infrastructure or existing polluting infrastructure, which will either lock countries into dangerous path dependencies or take them towards a different, 'green growth' trajectory. 
The main barriers to pension fund investment in infrastructure, which also apply to other institutional investors, were highlighted by the OECD in a recent report. ${ }^{45}$ The issues highlighted include the following, with some the main challenges discussed further below.

Table 2. Barriers to Institutional Investors Allocation to Infrastructure

\begin{tabular}{|c|c|}
\hline $\begin{array}{l}\text { Problems with } \\
\text { Government } \\
\text { Support for } \\
\text { Infrastructure } \\
\text { Projects }\end{array}$ & $\begin{array}{l}\text { - } \quad \text { Lack of political commitment over the long-term } \\
\text { - } \quad \text { Lack of infrastructure project pipeline } \\
\text { - } \quad \text { Fragmentation of the market among different levels of government } \\
\text { - } \quad \text { Regulatory instability } \\
\text { - } \quad \text { High bidding costs }\end{array}$ \\
\hline $\begin{array}{l}\text { Lack of Investor } \\
\text { Capability }\end{array}$ & $\begin{array}{l}\text { - } \quad \text { Lack of expertise in the infrastructure sector } \\
\text { - } \quad \text { Problem of scale of pension funds } \\
\text { - } \quad \text { Regulatory barriers } \\
\text { - } \quad \text { Short-termism of investors }\end{array}$ \\
\hline $\begin{array}{l}\text { Problems with } \\
\text { Investment } \\
\text { Conditions }\end{array}$ & $\begin{array}{l}\text { - } \quad \text { Lack of appropriate investment vehicles } \\
\text { - } \quad \text { Negative perception of the value of infrastructure investments } \\
\text { - } \quad \text { Lack of transparency in the infrastructure sector } \\
\text { - } \quad \text { Mis-alignment of interests between infrastructure funds and pension funds } \\
\text { - }\end{array}$ \\
\hline
\end{tabular}

Source: Adapted from (OECD, 2011)

\section{a) Lack of Government Support for Infrastructure Projects}

For infrastructure projects to be attractive, they ideally need to be part of a long-term strategy. If they are piece-meal and sustained policy support for them is in doubt, investors will remain wary. A long-term plan (for around 10-20 years) with high levels of transparency and evidence of good co-ordination between different levels of government (and in some cases, inter-country cooperation in regional settings) can make a big difference. Well-structured public-private partnerships (PPPs) can help develop a 'pipeline' supply of investment opportunities. This has been achieved in some OECD countries but is the exception, not the rule. The experience of countries such as Australia and Canada has shown how national infrastructure plans are an important signal to investors - including pension funds - of political commitments to infrastructure over the long-term.

\section{b) Lack of Investor Capability}

Infrastructure investments, particularly in the emerging world, are typically complex and difficult to understand. Institutional investors have traditionally invested in infrastructure assets through listed companies and fixed income instruments. But with a few noteworthy exceptions (such as some large Australian and Canadian, Danish and Dutch pension funds), they have generally shied away from direct, unlisted investments and are reluctant to take on substantial specific project risk. This lack of investor capability stems from the fact that the nature of infrastructure investments differs from other asset classes both in terms of high up-front costs and the scale of the projects in question. In addition, infrastructure entails a whole new set of risks which need analysing - from legal and regulatory risks (around tariffs fees and ownership rights), to construction, technology and operational risks to political and social risks. Examining these project-specific risks is very different from analysing listed companies and requires

45 See (OECD, 2011). 
dedicated resources that many smaller institutional investors lack and which can take years to build up (as has been the case at the Canadian public pension funds, for example, which are some of the most experienced infrastructure investors in the world).

An additional issue for institutional investors is the lack of objective and quality data on infrastructure investments. This makes it difficult to assess the risk in these investments and to understand the correlation with the investment outcomes of other sectors (i.e. whether infrastructure assets move in line with other asset classes, such as equity markets, or not).

The long-term nature of infrastructure investments may also run up against the short-term incentives driving institutional investors. ${ }^{46}$ Pension funds and insurance companies are, at least in theory, long-term investors, but they often face short-term performance pressures which may be preventing them from investing in long-term assets such as infrastructure. Such pressures for short-term risk-adjusted returns by investors are leading to inefficient capital allocation within companies, which can lead to unsustainable investments and indeed lower returns. ${ }^{47}$

\section{Regulatory Barriers}

In addition to information and knowledge barriers to infrastructure investing, there may be regulatory barriers in some countries which prevent pension funds from investing in such assets. Though investment restrictions are important to protect pension fund members, particularly in developing economies, there may be unintended consequences preventing investment in infrastructure through bans on unlisted or direct investments (for example carbon is sometimes viewed as a commodity which is subject to investment restrictions in some countries). ${ }^{48}$ It should be noted that the OECD does not recommend the use of 'investment floors' which require pension funds to invest in a particular asset class, and therefore would not support governments compelling pension funds to invest a certain percentage of their assets in infrastructure or clean energy projects.

In addition international accounting and funding rules may also be inadvertently discouraging institutional investors from investing in longer-term, illiquid or riskier assets such as infrastructure projects. Recent developments in accounting, in particular the introduction of fair value principles, have brought greater transparency and consistency to financial statements. However, the move towards fair value has also brought a greater focus on short-term market fluctuations, and some would argue that this has been to the detriment of the long-term investment horizon. For example, it has been suggested that he way pension funds are 'marked to market' in some countries allows for long term smoothing on the valuation of their assets and liabilities and thus enables them to hold a far larger proportion of their assets in illiquid investments such as property, private equity and infrastructure than funds in other countries.

$46 \quad$ For further details see (Della Croce et al. 2011) 'Promoting Longer-Term Investment by Institutional Investors : Selected Issues and Policies' These issues are being further investigated by the OECD via the long-term investment project (www.oecd.org/finance/lti).

47 For example, Haldane and Davies (at the Bank of England) found that "investment choice, like other life choices, is being re-tuned to a shorter wavelength," leading to irrational investment decisions - particularly with respect to projects of longer duration, which often yield the highest private (and social) returns. They show that across the public markets, long-term investment opportunities are routinely missed because cash flows are inappropriately discounted. In their report, they show that cash flows five-years out are routinely discounted as if they were eight-years out, and cash flows 30-years out are scarcely valued at all. They also document evidence that this pattern has been accelerating since the mid-1980s. See http://www.bankofengland.co.uk/publications/Documents/speeches/2011/speech495.pdf.

48 The OECD generally supports the use of the 'prudent person rule' for pension fund investing - see 'OECD Guidelines on Pension Fund Asset Management' http://www.oecd.org/dataoecd/59/53/36316399.pdf. 
Fair valuation is also at the heart of risk-based funding and solvency regulations as applied in certain countries to pension funds and as envisaged in the Solvency II framework for European insurers. Solvency II, commonly referred to as "Basel for insurers", is due to come in to effect 1 January 2014 and aims to reduce the risk exposure of European insurance companies through more stringent capital standards. Among other aspects, such regulations apply a different capital charge to different investments depending on their perceived riskiness -and again there is a concern that this could discourage investment in sectors such as infrastructure. ${ }^{49}$ It is also under debate whether such regulations should also be applied to pension funds in Europe.

The impact of solvency rules depends on how insurance companies and pension funds gain exposure to infrastructure projects. Insurance companies generally invest via debt instruments. The capital charge for bonds is given by a rating factor multiplied by the duration of the investment. The impact of the solvency rules would in this case come from the fact that long-dated bonds and /or those with lower credit ratings would require greater capital - with these being just the type of debt instrument, such as green bonds, which are potentially to be used to finance infrastructure and clean energy projects at scale. Insurance companies may increasingly favour AAA rated bonds at the expense of AA and A rated utility companies and quasi-public bodies. The key challenge is that bonds with a long maturity and with an investment grade rating in the lower end of the spectrum will require a significant capital charge. This would further reduce investment funds available to the energy sector, and ultimately the market scope of such initiatives as EU Project Bonds.

In the case of pension funds, ${ }^{50}$ concern has been expressed that risk-based solvency rules could hinder further allocation by pension funds into infrastructure assets due to the higher solvency charges they often entail, as many pension funds invest via equity structures rather than debt, and often via unlisted, private equity type instruments. There is some anecdotal evidence that such capital requirements have discouraged some investors from investing in infrastructure projects via equity assets. ${ }^{51}$ However, it is interesting to note that in countries where similar risk-based regulation has been introduced (such as the FTK solvency rules for pension funds in the Netherlands and the 'Traffic Light' solvency systems applied in Scandinavian countries) the impact on institutional investors' asset allocation is inconclusive. ${ }^{52}$

Where institutional investors see sufficient, steady, diversified risk-adjusted returns from clean energy projects (the latter being important as diversification acts as a reduction factor in Solvency II capital charges) they will still invest. However, the accounting and solvency regulations are not helping and may even be discouraging them from acting in their long-term capacity. Handing over financing from banks to institutional investors may not be easy as these loans were not necessarily structured to readily facilitate a

49 The proposed Solvency II regulation would likely require a $49 \%$ stress test (i.e. would the insurer still be able to meet its liabilities if these assets declined by this amount) for infrastructure equity and private equity (compared to a capital charge of $39 \%$ for listed equity) and $25 \%$ for real estate and infrastructure debt (NB this compares with a $0 \%$ capital charge for European government bonds - whatever their credit rating). For a full discussion of the impacts of accounting and solvency rules on long-term investing see (OECD, 2012f forthcoming) 'The Effect of Solvency Regulations and Accounting Standards on Long-term Investing'

50 The OECD has examined the mechanism used by pension funds in different countries - see (OECD 2012e forthcoming) 'Largest Pension Funds 2011 Survey'

51 For example, Storebrand and Vital, two of Norway's largest insurance companies have invested in long-term bonds issued by Gassled, a joint venture between oil and gas companies that transports gas from the North Sea to continental Europe and the United Kingdom. The insurers have shelved plans to invest in the equity part of the joint venture because of the perceived high capital charge. See 'Solvency II hampers attractive infrastructure investments', NRPN Nordic Region Pensions and Investment News Oct/ Nov 2011.

52 For details see (OECD, 2012g - forthcoming, 'The effect of Solvency Regulations and Accounting Standards on Long-term Investing'). 
long-term, investment-grade bond market issuance to fund the refinancing, which is what Solvency II type regulation will require. Financial innovations, such as effective targeted risk transfer techniques to enhance credit quality of projects, will become more important (see later section). ${ }^{53}$ Further analysis is required into the potential impacts of such international regulations on infrastructure in general and green projects in particular. The OECD is undertaking such research in 2012.

\section{c) Problems with Investment Condidtions}

One issue preventing institutional investors from further allocating to infrastructure investments is the lack of appropriate investment vehicles. As discussed, only the largest pension funds have the capacity to invest directly in projects. Smaller pension funds in particular require pooled investment vehicles. Collective investment vehicles, such as infrastructure funds, have been available to smaller investors, but problems with high fees and extensive leverage mean that these have become less popular since the financial crisis. ${ }^{54}$

There is also a lack of debt instruments such as bonds for institutional investors to access infrastructure projects, particularly for clean energy. This is notable since bonds remain the dominant asset class in portfolio allocations of pension funds (50\%) and insurance companies (61\%) across OECD countries (see Figure 7). HSBC and the Climate Bonds Initiative estimate the outstanding amount of bonds "strongly aligned" clean energy at USD 175 billion in 2011 (though it should be noted that this figure includes nuclear power and other non-infrastrucrure investments, such as rewnewable energy manufacturers). Given the scale of the USD 95 trillion global bond markets, clean energy bond issuance remains but a drop in the pond $(0.184 \%)$.

In addition, a specific issue relating to clean energy investments is that the size of the bond issuances tends to be too small for institutional investors who are looking to invest larger sums of capital (partly to justify the due diligence required and also to have a meaningful impact on their portfolios). Veys (2010) and others ${ }^{55}$ warn that the minimum typical issuance size for an institutional investment grade bond offering is about GBP 300 million. Barclays (2011) point out that the absence of secondary markets for green project finance debt has restricted the capital provision from private investors and institutions (excluding direct lenders such as corporate and investment banks). For example, asset backed securities or bonds, which allow investors to access secondary markets, make up less than $3 \%$ of green asset financing. ${ }^{56}$

53 See Standard \& Poor's, October 14 2011, 'Basel III and Solvency II Regulations Could Bring A Sea Change in Global Project Finance Funding'.

54 A new platform is emerging called Zanbato (www.zanbato.com), that connects smaller projects (USD 100 million) with institutional investors.

55 HSBC and Climate Bonds (2012 forthcoming) write that tapping the institutional investor market requires deal flow of minimum $\$ 300 \mathrm{~m}$ or preferably $\$ 500 \mathrm{~m}$.

56 (EU 25) only between 2004 and 2009, Source: Barclays and Accenture (2011) based on BNEF data. 


\section{Figure 8. Pension fund and direct insurers asset allocation for selected investment categories in selected OECD countries, 2010}
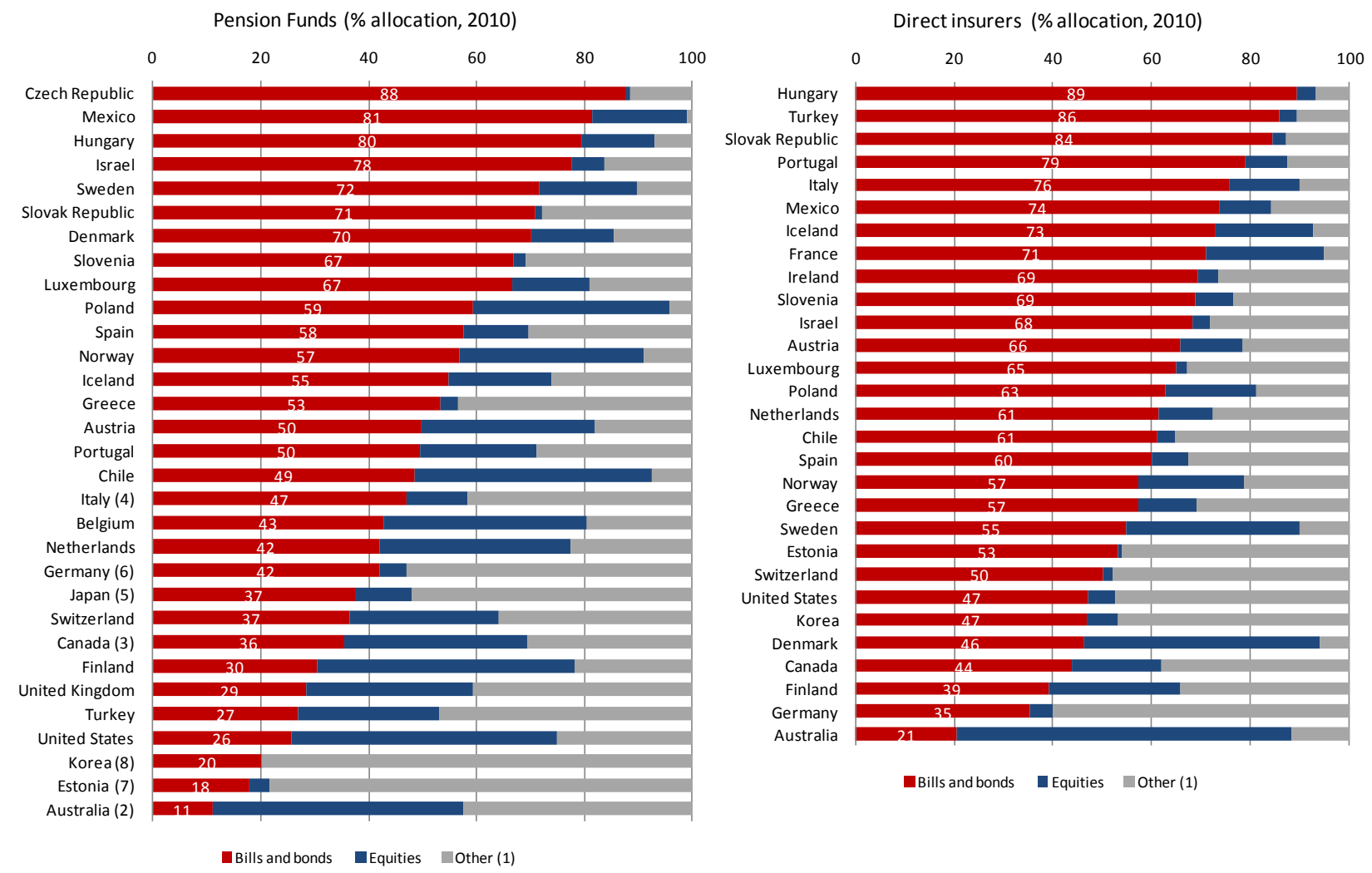

Notes:

1. For pension funds: The "Other" category includes loans, land and buildings, unallocated insurance contracts, private investment funds, other mutual funds (i.e. not invested in cash, bills and bonds or shares) and other investments. / For direct insurers: The "Other" category includes mortgage loans, loans other than mortgage loans, real estate and other investments.

2. Source: Australian Bureau of Statistics. The high value for the "Other" category is mainly driven by net equity of pension funds in life office reserves (16\% of total investment).

3. The high value for the "Other" category is mainly driven by other mutual funds ( $16 \%$ of total investment).

4. The high value for the "Other" category is mainly driven by unallocated insurance contracts ( $22 \%$ of total investment).

5. Source: Bank of Japan. The high value for the "Other" category is mainly driven by payable and receivable accounts $(24 \%$ of total investment) and outward investments in securities (19\% of total investment).

6. The high value for the "Other" category is mainly driven by loans $(29 \%$ of total investment) and other mutual funds ( $17 \%$ of total investment).

7. The high value for the "Other" category is mainly driven by private investment funds (65\% of total investment).

8. The high value for the "Other" category is mainly driven by unallocated insurance contracts ( $20 \%$ of total investment).

Source: OECD Global Pension Statistics and OECD Global Insurance Statistics and indirect investment through mutual funds. ${ }^{57}$

57 The GPS database provides information about investments in mutual funds and the look-through mutual fund investments in cash and deposits, bills and bonds, shares and other. When the look-through was not provided by the countries, estimates were made assuming that mutual funds' investment allocation in cash and deposits, bills and bonds, shares and other was the same as pension funds' direct investments in these categories. Therefore, asset allocation data in this Table include both direct investment in shares, bills and bonds and other assets 


\section{Box 5. Green Bonds}

Some interesting initiatives are underway to allow other institutional investors to make such clean energy investments via their fixed income portfolios - namely through the issuance of green bonds. These are broadly defined as fixed-income securities issued (by governments, multi-national banks or corporations) in order to raise the necessary capital for a project which contributes to a low carbon, climate resilient economy. Green bonds involve the issuing entity guaranteeing to repay the bond over a certain period of time, plus either a fixed or variable rate of return. They can be asset backed securities ${ }^{58}$ tied to specific green infrastructure projects or plain vanilla "treasurystyle" bonds issued to raise capital that will be allocated across a portfolio of green projects (such as the World Bank's issuances). ${ }^{59}$

In terms of the size of the market, the OECD estimate pure green bond issuance at around USD 16 billion in 2010. Bloomberg (2011) estimate a similar sized market $(\$ 13.9 \mathrm{bn})$ using a narrow definition, ${ }^{60}$ but using their broader definition (including corporate debt issued by companies that are partially exposed in the renewable energy or energy efficiency sectors) ${ }^{61}$ an estimated USD 200 billion of bonds have been identified. ${ }^{62}$ HSBC and the Climate Bonds Initiative estimate the outstanding amount of climate-themed bonds at USD 174 billion $^{63}$. Their largest sectors are transport at $\$ 119 \mathrm{bn}$, clean energy at \$29bn, and climate finance at \$22bn.

However, issuance so far remains but a drop in the pond compared with the USD 95 trillion total global bond markets. In some 30,000 separate deals, USD 6.05 trillion in bonds were issued in 2010. With these statistics as context, there is clearly scope for scaled up issuances of green bonds.

The largest specific green bond issuances so far have come from green or clean energy bond programmes by multilaterial development banks, such as the World Bank and European Investment Bank, totalling USD 7.2 billion. ${ }^{64}$ These bonds have received the highest AAA rating and have helped establish early confidence in the green bond market. The bonds were targeted at institiutional investors (NB it is interesting to note that the World Bank bonds were issued through "reverse inquiry", with Nordic pension funds and Japanese Uridashi market retailers specifically asking for green bonds that suited their investment requirements) as well as the retail sector, sovereign wealth funds, hedge funds and private equity (OECD, 2011). However, such issuances may have peaked (on an annual basis) due to stringent Multilateral Development Bank loan to capital requirements.

There is room for expansion in the government and asset-backed markets (OECD, 2011). For example, the US government has allocated USD 2.4 billion under a Clean Renewable Energy Bonds program to allow municipalities to finance public sector renewable energy projects. ${ }^{65}$ Encouraging steps are being taken via the green bank initiatives which various governments are currently in the process of setting up and which are likely to issue green bonds in the future. For example:

58 Asset backed or securitized bonds are similar to ordinary bonds but have specific assets whose revenues pay the interest and principal. An ordinary bond's payments are generally guaranteed by the company that issues them. In asset backed or securitized bonds a set of revenue generating assets are put into a special purpose company and these assets pay the bond holder their interest and principal.

59 http://treasury.worldbank.org/cmd/htm/WorldBankGreenBonds.html

60 Bloomberg's Tier 1definition includes: US Municipal bonds issued under the US Build America Bonds' Clean Renewable Energy bonds and Qualified Energy Conservation bond programmes (US\$ 0.8bn); Project bonds (mostly asset-backed, clear energy projects) (US\$ 6.5bn); IFI bonds (to fund loan programs for clean energy, climate change or energy efficiency) (US\$ 6.6bn).

61 Bloomberg's Tier 2 companies are divided into 2 groups: A1 with $>50 \%$ exposure to clean energy (US\$ $78.7 \mathrm{bn}$ ); A2 with $<50 \%$ but $>25 \%$ exposure (US\$137.4bn)

62 See also Climate Bonds Initiative and HSBC 2012

63 Ibid.

64 There has also been issuance in other regions. For example, in South Africa, the Government Employees Pension Fund invested R1bn in green bonds issued by the Industrial Development Corporation.

65 Of the USD 2.4 billion allocated under the US government programme only USD 600 million of bonds have been issued. Many municipalities who have won consent to issue the bonds have not yet done so. 
- $\boldsymbol{U K}$ : the UK government is planning to launch a Green Investment Bank (GIB) in early 2013 with initial capitalization of GBP $3 \mathrm{bn}$, potentially growing to GBP $18 \mathrm{bn}$ within 3 years if co-financing from private sector (including institutional investors) can be attracted, through new financial instruments. It will have a mandate to tackle risk that markets currently cannot handle, with an initial focus on non-domestic energy efficiency.

- Australia: the Australian Government will establish an AUS\$10 billion Clean Energy Finance Corporation (CEFC), planning to commence operations from 2013-2014. In order to overcome capital market barriers, the CEFC will invest in firms and projects utilising energy efficiency and low emissions technologies as well as manufacturing businesses that focus on producing the inputs required. It is intended that the CEFC will act as a catalyst to private investment that is currently not available for clean energy technologies.

- USA: Connecticut's Clean Energy Finance and Investment Authority (CEFIA) is the nation's first fully funded green investment bank established in 2011. The new entity aims at providing low-cost financing for clean energy and efficiency projects (including large-scale rooftop solar plants or commercial building retrofits or even high-voltage lines). The bank will be funded by a surcharge on residential and commercial electricity bills, which was previously paid into the state's Clean Energy Fund, amounting to USD 30 million a year. CEFIA will also administer the USD 18 million Green Loan Guaranty Fund. The total USD 50 million investment by the bank will enable Connecticut to leverage limited state resources with much larger amounts of private capital.

In addition to these governmental initiatives, aggregators can issue asset-backed securities ${ }^{66}$ that effectively aggregate portfolios of smaller loans into institutional investor-sized offerings. The market for asset-backed securities is still weak in the current low interest rate environment, but investment grade ratings can for the moment be achieved with partial or even full guarantees, all the while educating investors about the underlying projects in anticipation of the recovery of an asset-backed securities markets (IEA, 2012 - forthcoming). In total, Barclays (2011) finds that an estimated EUR 1.4 trillion of procurement capital could be securitized in "green bonds" (in the sense of asset-backed securities) across Europe between 2011 and 2020, making this the largest single financing instrument by value for the purchase of low carbon technology. Banks could provide primary debt, securitize it into "green bonds" and place the securities on the mainstream public markets with minimal impact on their balance sheets.

Large corporations such as utilities can do the same, contributing to developing an investment track record for underlying assets by linking their bond issuance to low carbon projects, while providing full and later partial credit rating through the corporate balance sheet. For example, a number of large bond issuances ranging from USD 500850 million in the US have raised capital for wind and solar farm construction, and renewable energy manufacturers are increasingly turning to the bond markets in the absence of restricted bank lending.

The covered bond market has been identified ${ }^{67}$ as being readily adaptable to leverage the scale at which bond finance can be delivered, so that a broader segment of the investment community can participate in clean energy finance. Covered bonds are asset-backed instruments which are also guaranteed by the entity issuing the bond, thereby providing low risk and comparably low funding costs. To develop this market, supranational and government agencies could identify criteria under which they could wrap or guarantee renewable energy projects, which would form a covered asset pool for the issuance of covered green bonds, allowing analysts to track the financial performance of the underlying covered pool of low-carbon assets, and thereby encourage the development of the market.

Covered bonds have been cited as a possible way to bridge the gap between the AAA-rated, supranational guaranteed 'climate' bonds and the highly specialised ABS sector. This could be achieved by adapting covered bonds for clean energy finance, which would attract new investors to the sector. Favourable attributes cited are that covered bonds already have a broad investor base and can be issued in almost 40 countries. They provide a high level of security and typically attract strong credit ratings. This is achieved through a dual recourse structure, which in many countries is governed under a specific legal framework. Bondholders have a preferential claim over the assets and

66 Asset-backed or securitized bonds are similar to ordinary bonds but have specific assets whose revenues pay the interest and principal. An ordinary bond's payments are generally guaranteed by the company that issues them. In asset backed or securitized bonds a set of revenue generating assets are put into a special purpose company and these assets pay the bond holder their interest and principal.

67 Climate Bonds Initiative, How Covered Bond markets can be adapted for Renewable Energy Finance 
associated cash flows in a dedicated 'cover pool', as well as an unsecured claim on the issuer to recover any shortfall (see Climate Bonds Initiative).

Green bond labelling allows investors to easily prioritize climate related investments. There is growing appetite from the investment community for investment-grade bonds that are specifically targeted at financing the low-carbon economy. Five of the world's largest insurers, for example, called in December 2011 for governments to create more climate-themed bonds so they can invest in such a market. ${ }^{68}$

Consistent preferencing across government jurisdictions, captured in a labelling scheme, would allow fund managers to hold multi-country climate-themed portfolios, increasing overall volume and thus liquidity in a thematic market.

\section{Problems with Clean Energy Investment}

In addition to the general problems surrounding institutional investors' allocations to infrastructure investments, there are also specific problems with clean energy investments which need to be addressed as outlined in the OECD's 'Policy Framework for Green Infrastructure Investment' (OECD 2012a). Some of these issues are discussed below.

\footnotetext{
${ }^{68}$ http://www.climatewise.org.uk/news/2011/12/5/creating-long-term-value-insurers-ask-for-action-so-they-can.html
} 
Table 3. The double challenge of low-carbon, climate-resilient infrastructure projects: risk analysis

\begin{tabular}{|c|c|c|c|}
\hline & & $\begin{array}{c}\text { Traditional risks linked to infrastructure } \\
\text { projects }\end{array}$ & $\begin{array}{l}\text { Additional risks linked to the climate change } \\
\text { aspects of infrastructure projects }\end{array}$ \\
\hline \multirow{4}{*}{ 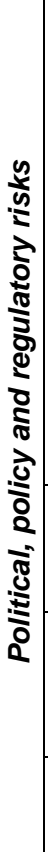 } & $\begin{array}{l}\text { Policy and } \\
\text { regulatory risk }\end{array}$ & $\begin{array}{l}\text { Lack of political commitment / policy certainty } \\
\text { over the long term on infrastructure planning; } \\
\text { Tariffs regulations to increase fees with } \\
\text { inflation fall behind schedule; } \\
\text { High bidding costs involved in the } \\
\text { procurement process of infrastructure projects } \\
\text { (lack of clarity about administrative rules; risk } \\
\text { of corrupt practices); } \\
\text { Fragmentation of the market and lack of } \\
\text { policy alignment among across different } \\
\text { levels of government. }\end{array}$ & $\begin{array}{l}\text { Lack of long term low carbon development or } \\
\text { adaptation strategies; } \\
\text { Trade barriers (tariff and non-tariff barriers) on } \\
\text { green technologies and/or their inputs; } \\
\text { Lack of harmonized environmental regulations; } \\
\text { Lack of political commitment / policy certainty } \\
\text { over the stability of specific forms of support to } \\
\text { green investment, such as feed- in tariffs. } \\
\text { Instability on the price of carbon, such as weak } \\
\text { or unstable environmental regulations; } \\
\text { Existence of fossil fuels subsidies that make } \\
\text { other investments more attractive to investors. }\end{array}$ \\
\hline & $\begin{array}{l}\text { Legal and } \\
\text { ownership rights }\end{array}$ & $\begin{array}{l}\text { Unknown future litigation possibilities, } \\
\text { planning consents not granted, lease running } \\
\text { out; risk to repatriation of earnings. }\end{array}$ & $\begin{array}{l}\text { Uncertainty about the legal status and property } \\
\text { rights of emissions permits. }\end{array}$ \\
\hline & $\begin{array}{l}\text { Political and social } \\
\text { risk }\end{array}$ & $\begin{array}{l}\text { Opposition from pressure groups; corruption; } \\
\text { Short-termism of politicians, limiting } \\
\text { infrastructure planning and investment. }\end{array}$ & $\begin{array}{l}\text { Additional forms of opposition to specific LCR } \\
\text { technologies or processes, such as carbon } \\
\text { capture and storage or wind farms, sea walls. }\end{array}$ \\
\hline & Currency risk & $\begin{array}{l}\text { Long-term investment horizon for } \\
\text { infrastructure and exchange rate fluctuations. }\end{array}$ & $\begin{array}{l}\text { Long-term investment horizon for climate } \\
\text { impacts and mitigation. }\end{array}$ \\
\hline \multirow{4}{*}{ 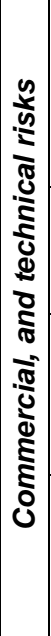 } & Technological risk & $\begin{array}{l}\text { Includes the risk of technology failure, } \\
\text { obsolescence or under-performance relative } \\
\text { to expectations. }\end{array}$ & $\begin{array}{l}\text { Particularly high in the context of low carbon } \\
\text { investments as they often involve new } \\
\text { technologies. The level of risk will depend on } \\
\text { the maturity of the technology and the track } \\
\text { record of the technology provider. }\end{array}$ \\
\hline & Construction risk & $\begin{array}{l}\text { Covering delays in the completion of the } \\
\text { project, the interface between the different } \\
\text { contracts of subcontractors or stakeholders. }\end{array}$ & $\begin{array}{l}\text { Lack of expertise in new climate mitigation and } \\
\text { adaptation technologies. }\end{array}$ \\
\hline & Operational risk & $\begin{array}{l}\text { Once the project has been constructed linked } \\
\text { to the ability of the management to operate } \\
\text { the asset, and to the decommissioning of the } \\
\text { project. }\end{array}$ & $\begin{array}{l}\text { Lack of expertise and track records in new } \\
\text { GHG mitigation and adaptation technologies. }\end{array}$ \\
\hline & Environmental risk & \multicolumn{2}{|c|}{$\begin{array}{l}\text { Unforeseen environmental hazards linked to an infrastructure project; } \\
\text { Climate risk, changing climate can damage the functioning of infrastructure; } \\
\text { Risk related to the uncertainty of climate change in infrastructure for adaptation. }\end{array}$} \\
\hline \multirow{2}{*}{ 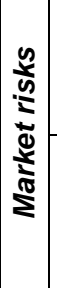 } & Business risk & $\begin{array}{l}\text { More competitors entering; } \\
\text { Change in consumer preferences and } \\
\text { demand. }\end{array}$ & $\begin{array}{l}\text { Technological advances; } \\
\text { Lack of familiarity with new low-carbon or } \\
\text { adaptation technologies. }\end{array}$ \\
\hline & Reputation risk & $\begin{array}{l}\text { Damage to a firm's reputation can result in } \\
\text { lost revenue or destruction of shareholder } \\
\text { value. Such damage may stem from local } \\
\text { sensitivities and needs. }\end{array}$ & $\begin{array}{l}\text { The climate policy context could address the } \\
\text { reputational risk though some new } \\
\text { technologies, such as wind, tide or CCS } \\
\text { projects could face local stakeholder resistance. }\end{array}$ \\
\hline
\end{tabular}

Source: Authors drawing on Della Croce et al., 2011; ODI, 2011; UN AGF, 2010; Ward et al., 2009; Muzenda, 2009. 


\section{Weak or non-existent environmental policies}

\section{1) Carbon Price / Harmful Subsidies ${ }^{69}$}

One of the biggest barriers to pension funds and other institutional investors moving into clean energy investments is the absence of policies to address the market failures which cause the mispricing of such investments in relation to existing, polluting technologies. This problem is confounded by a lack of clarity and consistency in terms of government commitments to environmental and climate policy. Aside from the pool of socially responsible investment assets, the broader universe of pension funds will not invest in projects or assets just because they are green - and indeed governments risk storing up future underfunding problems for their pension systems if they are forced to do so. These investments must deliver riskadjusted returns which are commercially competitive with existing high carbon investments.

Investors in infrastructure are working across fragile and fragmented environmental policy frameworks, giving uneven or weak signals for low-carbon investment. A strong and visible carbon price would improve the risk-adjusted return profile for low-carbon infrastructure investments. Instead, today's low carbon prices are insufficient to attract investors to riskier newer alternatives, making investment in more conventional options such as natural gas more likely. While gas is a less carbon intensive option than, for instance, coal, it perpetuates the on-going lock in to fossil fuel based energy systems.

A first step to integrating climate change externalities into markets is to examine where existing policies may prove harmful (e.g. subsidies related to fossil fuels, investment promotion for commercial developments in high climate risk areas, or land-use policies that induce urban sprawl and dependence on passenger vehicle travel). Institutional investors are certainly being given the wrong policy signal when governments are spending USD 400-600 billion on fossil subsidies (including USD 45-75 across the OECD) compared to USD 66 billion on support for renewable energy in $2010 .^{70}$

The forthcoming 2012 B20 Green Growth Task Force 'Recommendations to the G20' recommends ending subsidies and other inefficient forms of support for fossil-fuels as this will accomplish multiple and mutually reinforcing objectives - such as reducing public spending while increasing tax revenues and real incomes; reducing greenhouse-gas emissions and the overall cost of climate-change mitigation; and promoting the development and diffusion of low-carbon technologies and renewable energy sources. It recommends that countries should consider using some of the resources saved to reduce the impact of subsidy removal on the poorest and to support other public priorities, including green infrastructure.

69 This section draws from the forthcoming OECD paper "Policy Framework for Green Infrastructure Investment" (OECD 2012a).

70 (IEA 2011) See OECD-IEA Fossil Fuel Subsidies and Other Support webpage: www.oecd.org/iea-oecd-ffss

IEA defines support for renewables electricity generation as any incentive provided by governments in order to promote the deployment and application of renewable energy. The OECD published data in 2011 on fossil fuel support for producers and producers in 24 OECD countries. Work is now underway to collect information on the remaining 10 OECD countries that were not included in the first version of the inventory, and should be available by mid-2012. According to the IEA, fossil fuel consumer subsidies in developing countries stood at USD 409 billion in 2010, as measured by the price-gap approach. The value of fossil fuel producer subsidies in non-OECD countries remains a 'known unknown', but IISD Global Subsidy Initiative puts the value of fossil fuel production subsidies worldwide at USD 100 billion as a minimum per year. The latest OECD analysis highlighted in the March 2012 OECD Environmental Outlook to 2050 (OECD 2012)- shows that phasing out fossil fuels subsidies in developing countries could reduce by $6 \%$ global energy-related GHG emissions, provide incentives for increased energy efficiency and renewable energy and also increase public finance for climate action. 
Difficulties in implementing first best policies to price carbon on a genuinely global basis have meant that many clean energy projects still need support measures in order to be commercially viable. Ideally, such support measures would be transparent, predictable and of long enough duration to match the longterm characteristics of the new infrastructure that is needed. The long-time frames required for infrastructure project development makes businesses and investors particularly vulnerable to regulatory changes. Policy risk remains high on the watch list of many institutional investors since experience with the evolving regulatory framework for climate change has generated substantial policy uncertainty and financial risk for investors in new (e.g. low-carbon) technologies and infrastructure.

Although clean energy technologies, particularly solar photovoltaics and onshore wind, continue to fall in price and approach competitiveness with fossil-fuel power, some of the government support measures that could ensure that the sector maintains its growth trajectory are currently being wound back.

Figure 9. Levelised Cost of Electricity Q1 $2012(\$ / M W h)^{71}$

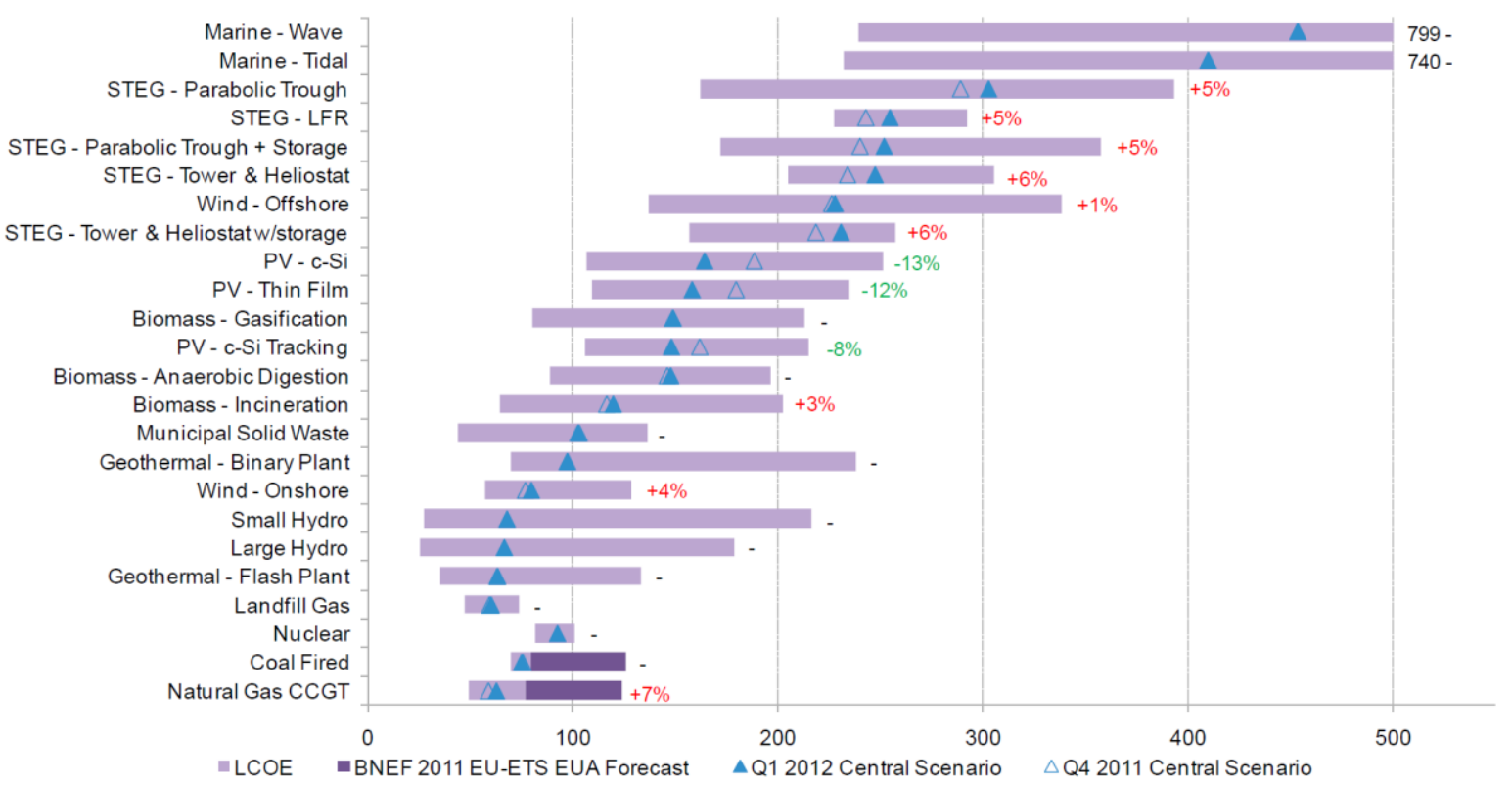

Source: Bloomberg New Energy Finance Input to OECD Workshop: Catalysing Investment in Low-Carbon, Climate-Resilient Growth (November, 2011)

Note: Carbon forecasts from the Bloomberg New Energy Finance European Carbon Model with an average price to 2020 of $\$ 33 / \mathrm{mtCO} 2$. Coal and natural gas prices from the US Department of Energy EIA Annual Energy Outlook 2011 and internal forecasts. Percentage change represents change from Q4 2011.

71 The levelised cost of electricity (LCOE) of a given technology represents the price at which a project owner can sell power and earn an acceptable return on his original investment. The LCOE is determined almost entirely by two factors: the cost of the equipment needed for a clean energy project and the cost of the capital needed to finance that project (Source: BNEF). 
Indeed clean energy investment fell sharply "squeezed by policy uncertainty" in the first quarter of 2012 according to Bloomberg New Energy Finance. ${ }^{72}$ The weak first quarter 2012 number was attributed to the destabilising uncertainty over future clean energy support in both the European Union - driven by the financial crisis - and the US - driven by the expiry of stimulus programmes and the electoral cycle. ${ }^{73}$

Finanical institutions are currently developing products to offer policy risk insurance which would protect investors against such retroactive changes. ${ }^{74}$

Unintended consequences of ownership regulation also need to be considered. For example, 'unbundling' policies ${ }^{75}$ preventing ownership of energy production and distribution companies could require institutional investors to divest some of their holdings. It is recognized that the EU energy sector must function on a level playing field; however, investors are being forced to choose between acquisitions of equity interests in transmission networks and in production and supply assets, often with no clear benefit to the market liberalisation agenda. ${ }^{76}$

\section{3) New technology}

Although clean energy tends towards becoming less and less policy dependant as the costs continue to decrease, clean energy investments are still riskier than established carbon intensive technologies. Existing infrastructure is based on old, well-proven technology, usually deployed on a large scale. Electric utilities, for example, built distribution networks that covered their served areas, and depreciated their assets over 40 years. The economies of scale in conventional generation, and regulated exclusivity, have made utility assets low-risk investments, easily financed with conventional low-risk project finance. The capital intensity of some clean energy technology (such as carbon capture and storage - CSS) is also a challenge.

Low-carbon projects are quite different. In many cases there is little data about the long term performance of these systems: they are often not "utility-scale", their value is uncertain and they are therefore perceived to be risky. This is obviously the case with technologies still at the developmental stage (such as wave and tidal generation) but applies even to clean energy projects such as wind and solar that are close to parity with conventional technologies. As a result, much higher returns and financing costs

72 BNEF Press Release 12 April 2012 http://bnef.com/PressReleases/view/208.

73 In the US, the key support mechanism for wind - the Production Tax Credit - is due to expire at the end of 2012 unless Congress agrees to extend it; while in Europe, governments in key countries such as Spain, Italy, Germany, Poland and the UK have announced cuts in incentives for renewable power projects, in some cases leaving investors guessing about their likely future returns.

74 Citibank, along with a number of other organisations, has proposed that a multgovernment policy risk insurance scheme be developed. This would be a new type of monoline insurance where risk is shared by participating governments using a co-insurance scheme. Confidence in the scheme would be enhanced with equity participation by governments, providing some incentive to avoid changes in policy. As proposed by Citibank, the facility would be backed primarily by governments with technical expertise provided by the insurance sector. Similar tupes of insurance might also be offered for a project's purchasing powe agreements. These proposals arer currently being further developed by the Climate Bonds Initiative and Climate Policy Initiative, incollaboration with a number of investment banks and insurers.

75 Contained in Chapters IV and V of Directive 2009/72/EC on electricity, Chapters III and IV of Directive 2009/73/EC on gas and Article 3 of Regulation 714 of 2009 on electricity ("Third Energy Package")

76 The unbundling provisions might operate more effectively if individual impact assessments were to be conducted on each application for certification, in order to establish whether any other interests held by the applicant in production or supply would be expected to give rise to a risk of conflicts of interest (Low Carbon Finance Group). 
are required compared with a conventional utility-scale energy plant. Additionally the cost of evaluating these risks is too onerous for most financial asset buyers. Consequently there is a very small pool of private capital available to invest in this form of energy infrastructure asset. Such projects must generally be financed entirely with equity which is a challenge since the current venture capital and private equity markets are unsuited for high-capital project investing (Firelake Capital, 2012).

Firelake Capital highlights technology risk as one of the main barriers for large institutional investors financing clean energy projects. This is defined as the risk that the system being installed does not work as specified. For existing electric utilities, this risk is mitigated by a hundred years of experience building power plants, and by performance guarantees issued by engineering and construction firms. Similarly, for solar projects this risk is mitigated by data from existing installations, and, where there is little data, occasionally by insurance. Currently this performance data is closely held by project developers as a barrier to competition, increasing returns to incumbents but slowing adoption by other market participants. Deployment of low-carbon infrastructure would be greatly accelerated if there were standard methods to measure and report the characteristics of systems and their components.

Institutional investors are not venture capitalists. They are looking for investments which provide steady, low correlation, long-term, and preferably inflation adjusted income streams. They are therefore likely to invest in established and mature technologies. However, much clean energy technology remains at the pre-commercial stage. Traditional venture capitalists are willing to take risk but want very high returns, characteristic of low-capital, fast moving industries- including yet unproven clean energy. Traditional institutional investors are interested in low-risk, low-return investments, characteristic of bonds and some infrastructure investments. Clean energy does not fall squarely into either camp - with inherent risks of any new and unproven technology but the lower return characteristics because of high-capital, decades-long infrastructure investing. While the entire clean economy value chain needs more capital, there is a particular dearth of funding in the first commercial project stage for new technologies because the financing is not appropriate for either of these traditional investments groups. It is an undesirable riskreturn point. It is critical to get to lower-cost technologies because as the technologies become lower in cost there is less (or no) dependency on subsidies and more flexibility around financing options. Most new technologies will, at some stage, require both the 'push' of research, development and demonstration (RD\&D) and the 'pull' of market deployment. The overriding objective should be to reduce risk, stimulate deployment and bring down costs. Evidence suggests that a large proportion of breakthrough innovations tend to come from new firms that challenge existing business models. Thus, government measures to remove barriers to entry and to support the growth of new firms have an important part to play. ${ }^{77}$

77 While the least mature technologies may require public support for research, development and demonstration, technologies that are technically proven, but more still more expensive than existing alternatives may require support to lower capital costs. Many countries have opted to provide tax- and other financial incentives to directly lower capital costs of low-carbon investment options. Recent OECD analysis examines this cluster of policies aiming to reduce the capital cost of investment in physical infrastructure (Kalamova et al., 2011) The analysis underscored a range of market barriers that raise the costs of capital to the renewable energy sector. In particular, technology immaturity of "clean" energy technologies increases the difficulties associated with accurately pricing relative risk of these investments, making it more difficult to obtain financing at reasonable costs compared to fossil fuel options. OECD (2009) estimated that investment in R\&D is necessary to make possible achievement of aggressive GHG emission targets, and can cut costs of mitigation of doing so. Yet the IEA (IEA 2011) estimate the difficulties of doing so: to achieve a $50 \% \mathrm{CO}_{2}$ emissions reduction objective, funding for R\&D in low-carbon technologies will need to be two to five times higher than current levels - and the money must be spent wisely. 
Figure 10. Market Deployment

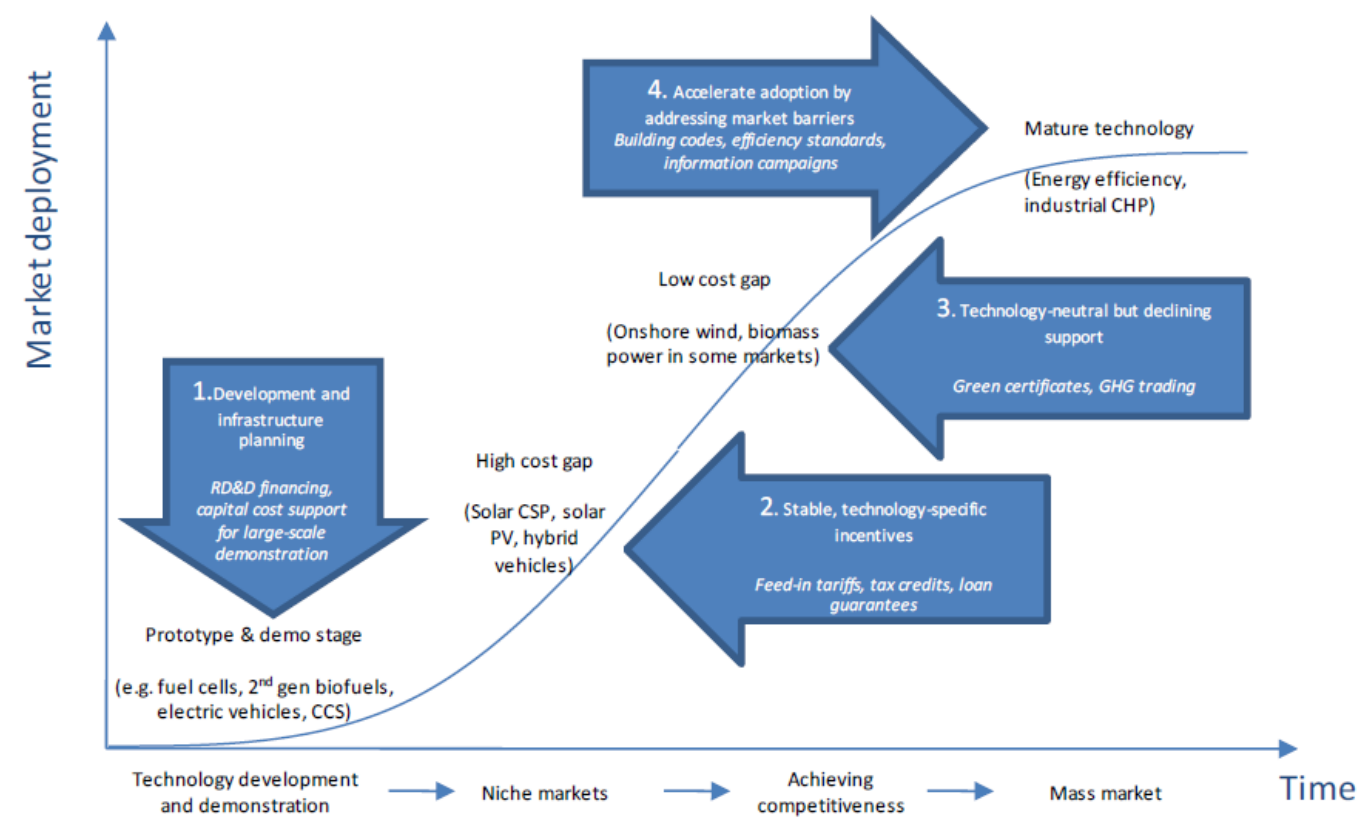

Note: The figure includes generalised technology classifications; in most cases, technologies will fall into more than one category.

Source: IEA (2010), Energy Technology Perspectives 2010, Kalamova, Kaminker and Johnstone, (OECD, 2011)

\section{Other risks particular to clean energy}

To attract institutional investment into clean energy projects these should be structured as attractive investment opportunities for investors, providing risk return profiles that match their expectations (which, as mentioned previously, generally centre on steady income flows). However, as the OECD finds, there is commonly a mismatch been the long-term, relatively low risk needs of institutional investors and the financing vehicles that are available to them (OECD, 2011).

Buyer risk - Clean energy projects involve specific risks, including those involving regulation, which investors are not accustomed to analyzing. For example, hedge fund Firelake Capital highlight buyer risk as a major barrier to clean energy investing. This is the risk is that there will not be a buyer for the electricity output of the project. For existing electric utilities this risk is mitigated by exclusivity, consumer dependence on electricity and regulated monopoly status that allows the unused electricity generation capacity to be charged to the customers. With many sub-utility solar projects, the output is used by the owner of the project. Many others operate under long-term contracts - power purchase agreements, which have a risk of default. This lack of certainty is a major risk for financing low-carbon projects. Where the projects are located in developing economies, currency and political risks may also be involved. Qualifying as investment grade is often an issue for clean energy investments, with ratings agencies typically awarding BB or lower ratings ${ }^{78}$ for wind and solar project bonds (Firelake Capital, 2012).

Volumetric risk - linked to this and of particular concern for securitisation of clean energy assets such as wind (see OECD 2011, Breeze Bonds Case Study) is volumetric risk. Often the risk from onshore

78 S\&P has given investment grade ratings in the past to renewable energy bonds (wind and solar), although some have deteriorated to BB or B category. 
wind and solar plants comes after the project is operational and is tied to production volatility (the reliability of an energy production forecast is particularly an issue for wind farms) ${ }^{79}$ Compared to a conventional power plant, where future production will typically be a known quantity, the variables for renewable energy alternatives and the lack of historical data on them can make it difficult to assess production output. For example, wind performance in northern Europe throughout 2010-2011 was significantly lower than predicted in the winter months, when the best wind is anticipated and a number of projects experienced low coverage ratios. Over the past year wind peformance insurance products have been offered by Swiss Re and Galileo Insurance; the market has yet to fully absorb the impact of these.

\section{Box 6. Risks in Securing Climate Change Finance}

In 2010 Standard \& Poor's and Parhelion Underwriting Ltd. hosted a Climate Change Financing roundtable. In order to identify the barriers that prevent investment by institutional investors, participant identified and categorized perceived risks. The top right area of the chart illustrates the risks with the highest degree of 'probability' and 'severity'. Whilst all issues need attention, this is the area where policy makers in particular need to concentrate their initial efforts.

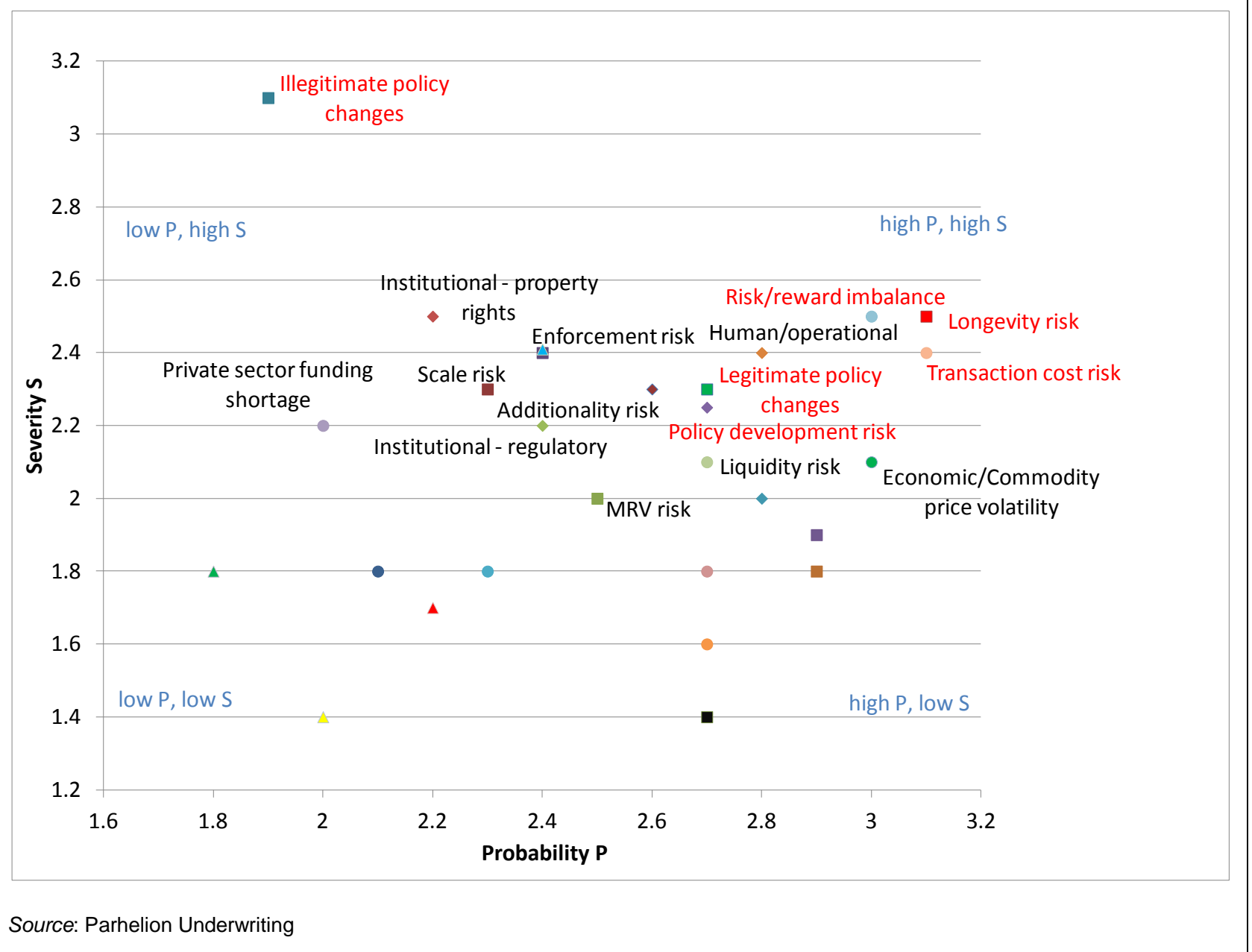

79 It is a problem and a concern for solar but generally the energy production of a PV plant is simpler than estimating the production of a wind farm. Generally, the depth of the data is stronger and there is lower volatility in the solar resource compared to the wind, and generally there are fewer variables to be considered in the estimation. 
The following risks are particularly worthy of comment:

Longevity Risk is perceived to have the highest probability and severity. Investors are most concerned with the apparent mismatch between the long-term nature of capital commitments inherent in climate change financing and the relatively short time frame of climate change regulations. Investment horizons and/or capital commitment periods can range from 20 years for a reasonably sized renewable energy project to 50 years or more for a climate change adaptation-related investment. Further, government climate-legislated targets are subject to change and investors are typically reluctant to rely on them fully.

Illegitimate policy and regulatory changes pose a real threat to climate change financing. If a country is not considered a safe place to invest for normal commercial activities, it is also unlikely to attract climate change finance. One possible way forward would be to offer affordable political risk insurance, which can protect investors against illegitimate policy changes. The risk of Legitimate Policy Changes also is probable and significant. These changes refer to the risk that policies may be amended in the ordinary course of government and from government to government in the same country as political and economic circumstances change. That both Illegitimate and Legitimate policy changes are high on the risk agenda of investors and suggests that they will more likely get involved in climate change financing if governments and regulators create a regime beyond the normal reach of political interference.

Economic/Commodity Price Volatility Risk also ranked among the top five risks for high probability and severity. This reflects that other basic and pressing needs may detract from climate change finance flows in periods of low or negative economic growth. Investors in climate change financing are also concerned that a lack of a well-trained workforce to implement projects (that is, Human/Operational risk) will significantly affect the willingness to invest.

Linked to the political risk, investors among fear a lack of property rights and/or the legal system in the host country where a particular low-carbon economy investment is made (that is, institutional and Property Rights Risk). Climate change finance includes flows from the developed world to the developing world, where institutions and property rights are often weaker. So countries seeking to attract climate change finance may need to strengthen their governance and accountability. This issue is also linked to Enforcement Risk, where investments in a developing country are liable to expropriation because the legal system is less robust and rights are less well established than in the developed world. Investors perceive Enforcement Risk to be severe for climate change investments.

The relatively high probability and severity attached to the Risk/Reward Imbalance shows that financiers are concerned that insufficient returns will be generated given the risks involved in a project. This illustrates a key point that it's not sufficient to create a return for investors; the return must be attractive relative to all other investment opportunities. Therefore, to stimulate institutional investors' involvement in climate change finance, the returns expected on climate investments must be commensurate with perceived levels of risk and also competitive with the returns on normal business investments. As a consequence, risk transfer instruments, and especially insurance, have an important role to play.

The relative levels of probability and severity for Transaction Cost Risk (high) against Complexity Risk (relatively low) provide an interesting comparison. Investors and funders are able to deal with the complexity of a climate change financing project--provided it does not add significant costs to a transaction, thereby reducing the project's risk-return characteristics.

Source: Parhelion and S\&P 2011

Many of the factors that weigh against institutional investors taking more interest in clean energy infrastructure can be broadly described as different species of risk. Most institutional investors are looking to make clean energy investments via well known debt instruments such as bonds. Most require that these bonds carry at least investment grade ratings. Institutional investors rely on agencies' ratings to give them guidance and comfort especially in new, fast-moving areas. However, risks specific to clean energy related projects make this vital investment grade rating difficult to secure. Ratings agencies are (naturally) conservative particularly when trying to assess very long-term projects or contracts particularly if there is a 
limited long term-performance history on which to draw. The only way around this is to find a creditworthy entity prepared to step in and take the risks. There are few such non-government backed entities in existence which makes it likely that governments or multi-lateral agencies will have to shoulder these risks if they wish to mobilise the very significant sums required.

\section{Box 7. Clean Energy Risk Mitigation}

Governments and International Finance Institutions have been working to improve deal flow in clean energy investments, ensuring adequate, investment-grade deals at scale come to the market for institutional investors to invest in (for example with public sector finance investing alongside private sector and institutional investors or taking subordinated equity positions in funds). Addressing market barriers in private capital markets by shaping transitional financial instruments enables investors to deploy their capital where commercial (or near-commercial) opportunities exist. Leveraging in this context refers to the mobilization of private sector capital through the use of public sector finance and financial instruments. Public finance can 'crowd in' private capital by compensating private investors for what would otherwise be lower risk-adjusted rates of return than they would normally seek (AGF, 2010).

One example of the use of such leveraging mechanisms is the Project Bond Initiative launched by the European Union. The principal idea behind the Europe 2020 Project Bond Initiative, is to provide EU support to companies issuing bonds to finance large-scale infrastructure projects, mainly in the transport, energy and telecommunication sectors. The projects have to meet certain eligibility requirements, which include sustainability or green aspects (NB the European Union guidelines for sustainable transport will be reformed and strengthened from 2014). The aim is to access new pools of capital like institutional investors. The initiative will create a mechanism for enhancing the credit rating of bonds issued by project companies themselves. There are various ways this could be achieved: one possibility is for the EIB to provide the higher-risk subordinated debt finance to credit enhance the bonds issued by a project company. This could be done under a risk sharing agreement with the EU budget similar to that which is already used to guarantee certain risks associated with transport projects.

Governments and/or multinational agencies can use so-called "public financing mechanisms" to provide cover for risks which are new to investors or cannot be covered in existing markets (UNEP-FI, 2009). These include loan guarantees and insurance options. For example, some form of public / private partnership will be needed to mitigate regulatory risk. ${ }^{80}$ Specialist underwriter Parhelion (2012) has proposed the creation of a public / private funded Green Insurance Agency to make available to investors insurance policies to underwrite the specific risk of changes in policy and other insurance policies that the private sector are unable to do on a standalone basis. Understanding the effects of such mechanisms and how to make the best use of public funds to leverage private sector investment into green projects is of prime importance and deserves further analysis (for example, there is no uniform methodology to calculate leverage ratios of public to private finance, and different financial institutions report this ratio in different ways, whilst guarantees tend to be 'blunt' instruments, covering a blanket of commercial risks rather than targeted specific risks). ${ }^{81}$

$80 \quad$ See Parhelion (2012), 'The Role of Insurance in Climate Policy'.

81 See (Brown and Jacobs 2011). 


\section{Public Finance Mechanisms (PFMs)}

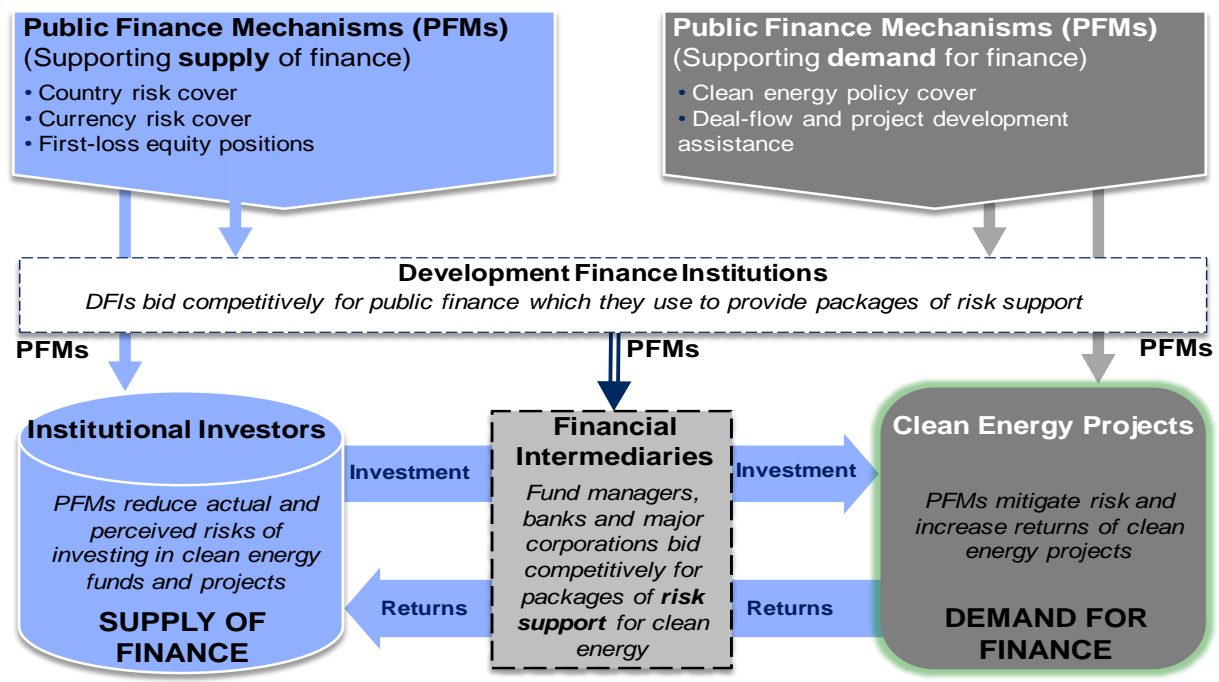

Source: OECD Analysis adapted on UNEP-FI 2009 research report

In addition to governments and other international organizations providing such risk mitigation and credit enhancement tools, reviving this role for the insurance industry (in particular the monoline insurers) and from other financial sector players will be important (for example Goldman Sachs recently announced their interest in the credit enhancement business).

Direct corporate funding is another relatively untapped market that could grow in future. For example, Danish utility company DONG Energy took responsibility for the construction risk of an offshore wind farm which Danish and Dutch pension funds then invested in. DONG sells off around 50\% of each individual wind farm to co-investors so that they can recycle the capital into new projects and have managed to build relationships with a number of pension funds, which they believe are a good profile match for offshore wind farms as they are interested in long-term revenue streams and projects where they can invest larger amounts of capital in one long-term project.

DONG was able to use its complex financial engineering to alter the risk-return profile of this investment so as to make institutional contributors comfortable (See CPI San Giorgio Group Case Study, 2012 forthcoming). The financial engineering relied on three pillars. First, DONG "de-risked" the investment by deploying PPAs, construction management and O\&M agreements. These significantly reduced uncertainties relative to the three largest cash flow components. Second, the amount that the financial investors have had to pay DONG for the purchase of the stake depended partially on the fulfillment of specific conditions (construction cost \& time). Third, DONG lent money to the financial investors to help them acquire the minority stake in the wind farms (vendor financing).

A further risk is the issue of defining green investments. Currently there is no standard definition of 'green' and the term is used very widely and applied differently in different asset classes. ${ }^{82}$ A common understanding of 'green' is needed so that insurance and guarantees can be reliably offered, and investors can have confidence that the funding they are providing to clean energy projects is directed in the manner in which they expect. ${ }^{83}$

82 See (OECD 2012b forthcoming) 'Defining and Monitoring Green Investments'

83 For details on an on-going project see Climate Bonds Initiative - www.climatebonds.net 


\section{CONCLUSIONS}

The preceding discussion of barriers raises at first sight a series of 'Catch 22' challenges: for instance, if there was a robust carbon price, clean energy would be more competitive and a variety of risks would be reduced. In the absence of robust carbon prices special policies may be needed to tip the balance - but special policies increase regulatory risks. It is very easy to keep returning to a relatively simple menu of first best policy advice. But that is not the world we live in.

On the other hand, even in a second or third best policy world, there are large pools of capital that need stable, long-term investment opportunities. And whatever the policy settings, demand for energy will grow so investments in energy infrastructure will be made one way or the other. How clean that infrastructure is will depend on all the policy interventions and omissions in place. So the key question is, in the absence of climate policy certainty, can steps can be taken immediately to increase the flow of capital to the clean energy sector without prejudice to the longer term development of climate policy?

The answer is yes - and there has been some progress. Debate on how to encourage institutional investors' participation in clean energy projects has begun. A forthcoming OECD report focuses on the domestic policy dimension of private climate finance, and in particular how to reform or design policies to provide lasting incentives for Low-Carbon, Climate-Resilient (LCCR) infrastructure investments. The domestic policy agenda includes not only strengthening investment policies, while implementing economically sound climate policies, but also building institutional and management capacity within governments to understand and integrate climate change into mainstream structural economic and sector policies.

Figure 11. Elements of an Integrated Domestic Policy Framework for Green Infrastructure Investment

\begin{tabular}{|c|c|c|}
\hline \multirow{6}{*}{ 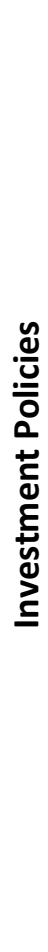 } & ELEMENTS OF A GREEN INVESTMENT POLICY FRAMEWORK & \multirow{6}{*}{ 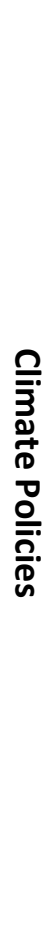 } \\
\hline & $\begin{array}{l}\text { STRATEGIC GOAL SETTING AND POLICY ALIGNMENT } \\
\text { Clear, long-term vision and targets for infrastructure and climate change; policy alignment and } \\
\text { multilevel governance, including stakeholder engagement }\end{array}$ & \\
\hline & $\begin{array}{l}\text { ENABLING POLICIES AND INCENTIVES FOR LCR INVESTMENT } \\
\text { Sound investment policies to create open and competitive markets; market based and } \\
\text { regulatory policies to "put a price on carbon", remove harmful subsidies and correct for } \\
\text { environmental externalities }\end{array}$ & \\
\hline & $\begin{array}{l}\text { FINANCIAL POLICIES AND INSTRUMENTS } \\
\text { Financial reforms to support long-term investment and insurance markets; innovative financial } \\
\text { mechanisms for risk-sharing such as green bonds; transitional direct support for LCR investment }\end{array}$ & \\
\hline & $\begin{array}{l}\text { HARNESSING RESOURCES AND BUILDING CAPACITY FOR A LCR ECONOMY } \\
\text { R\&D, human and institutional capacity building to support LCR innovation, monitoring and } \\
\text { enforcement, climate risk and vulnerability assessment capacity }\end{array}$ & \\
\hline & $\begin{array}{l}\text { PROMOTING GREEN BUSINESS AND CONSUMER BEHAVIOUR } \\
\text { Corporate and consumer awareness programmes, corporate reporting on climate change, } \\
\text { information policies, outreach }\end{array}$ & \\
\hline
\end{tabular}

Source: (OECD 2012a forthcoming), Towards a Policy Framework for Green Infrastructure Investment. 
Interesting initiatives are underway. For example, to encourage institutional and other investors to increase their allocations to infrastructure projects, governments in countries such as Australia and Canada have announced clear project pipelines. Meanwhile, major pension funds, insurance companies and sovereign wealth funds have made major commitments to clean energy projects and institutional investors have come together to improve their capability and knowledge and to use their long-term potential to invest in infrastructure and green projects.

On the innovative financing side, the issuance of green bonds and the growth of a nascent market is an interesting development. Governments, multilateral development banks and other public sources are also working on risk mitigation and credit enhancements tools to ensure that institutional investors gain access to financial vehicles with the appropriate risk-return profile.

Initiatives such as these can be built on and encouraged - and more can be done. Governments have begun to make progress when it comes to supporting institutional investors' capital allocations for clean energy projects, but more needs to be done if the transition to a green economy is to be achieved. Ministers can take a lead in encouraging further efforts to support institutional investors financing in the clean energy space - by providing clearer support in terms of the environmental policy backdrop in general (through a carbon price and / or the redirection of fossil fuel subsidies), through transparent and stable support for clean energy projects, and through dramatically increasing efforts to pool public funding to leverage private investments, in part by scaling up risk mitigation and co-investment funding structures.

Ministers can also work more closely with the institutional investors themselves to better understand their needs. This requires improving the data and monitoring of their clean energy investments, including international harmonisation, performance measurement and rating approaches for alternative investments more generally and green investments in particular. Energy and Environmental Ministers need to work with their Finance colleagues to ensure that the investment and regulatory environment is supportive and that institutional investors are offered appropriately structured financing vehicles.

Over and above the vital issue of overall climate policy signals, more discussion and analysis is needed on the following questions if institutional investors are to play an expanded role in financing clean energy projects:

- What are the most efficient and effective financing tools, public finance mechanisms and cofunding structures for leveraging private sector financing? How can successful experience with such tools and mechanisms be scaled up and applied more widely?

- What are the implications of financial regulations such as Basel III and Solvency II for the financing of clean energy? How can governments and financiers work together to address any possible constraints they might impose?

- Given that bonds remain the dominant asset class for institutional investors, which mechanisms could governments provide to increase fixed income allocation to green investments? How can securitisation be harnessed to scale up the green bond markets?

- Are standards for clean energy investment vehicles required? If so, who might play a useful role to move these forward? How can data be better collected and monitored to provide transparency about the performance of green investments?

The OECD continues to work in these areas ${ }^{84}$ - and it is hoped that this report will provide a platform to spark further ideas and debate.

84 Notably the Organisation has drafted policy actions to support pension fund investment in green infrastructure for the June 2012 G20 Leaders' Summit. 


\section{REFERENCES}

AGF, (2010), AGF (2010) 'The Report by the UN Secretary-General's High-level Advisory Group on Climate Change Financing.'

Association of British Insurers (ABI), (2011), 'Key Insurance Facts 2010'

http://www.abi.org.uk/Facts_and_Figures/Facts_Figures.aspx

Barclays and Accenture (2011), Carbon Capital: Financing the Low Carbon Economy, Barclays PLC, London.

Bloomberg New Energy Finance (BNEF), (2011), 'Bond, green bond - licensed to thrill investors?'

BNEF, (2012), Renewable Energy Dashboard: http://bnef.com/Renewables/

Bolton, Patrick, et al. (2012), Sovereign Wealth Funds and Long-Term Investing. Columbia UniversityPress, New York.

Brown, J., Jacobs, M., (2011), 'Leveraging Private Investment: The Role of Public Sector Climate Finance', Overseas Development Institute Background Note http://www.odi.org.uk/resources/docs/7082.pdf

Capital Market Climate Initiative (CMCI), (2012), 'Principles for Investment Grade Policy and Projects'

Climate Bonds Initiative (2012), How Covered Bond markets can be adapted for Renewable Energy Finance and how this could Catalyse Innovation in Low-Carbon Capital Markets.

Climate Bonds Initiative and HSBC, (2012), 'Mobilising Bonds for the Climate Economy: Current Practice and Future Potential'.

Della Croce, R., Stewart, F., Yermo, J., (2011), 'Promoting Long-term Investments by Institutional Investors' OECD Journal of Financial Market Trends, Volume 2011- Issue 1 http://www.oecd.org/dataoecd/51/21/48616812.pdf

Environmental Defense Fund (2011), 'Energy Efficiency Financing Barriers and Opportunities'.

Firelake Capital (2012), 'Financing Low-Carbon Energy Infrastructure: Scaling Capital and Mitigating Risk for Renewable Energy Deployment'.

Haussma, Velasco and Rodrik, (2008), 'Growth Diagnostics', in Stiglitz, J., and Serra, N., (eds), 'The Washington Consensus Reconsidered: Towards a New Global Governance'

Hawley, J., Johnson, K., Waitzer, E., (2011), 'Reclaiming Fiduciary Duty Balance”, Rotman International Journal of Pension Management, Volume 4 -Issue 2, Fall 2011

International Energy Agency (IEA) (2012), Tracking Clean Energy Progress: Energy Technology Perspectives 2012 excerpt as IEA inputs to the Clean Energy Ministerial, OECD/IEA, Paris. 
IEA (2012 - forthcoming), 'Energy Technology Perspective', IEA, Paris.

IEA (2011), 'World Energy Outlook', IEA, Paris.

IEA (2011a), 'Joint Public-Private Approaches for Energy Efficiency Finance’, IEA, Paris.

IEA (2008) 'Energy Technology Perspectives : Scenarios and Strategies to 2050'

Justice, (2009), Justice, Sophie (2009) 'Private financing of renewable energy: A guide for policy makers'. UNEP-SEFI.

Kalamova, M., Kaminker, C., and Johnstone, N., (2011), 'Sources of Finance, Investment Policies and Plant Entry in the Renewable Energy Sector', OECD Publishing Paris http://www.oecdilibrary.org/docserver/download/fulltext $/ 5 \mathrm{~kg} 7068011 \mathrm{hb} . p d f ?$ expires=1332148966\&id=id\&accname =guest\&checksum=6EEA531BD667B7FC0D945446CDDC01E5

OECD, (2006), 'Guidelines for Pension Fund Asset Management' http://www.oecd.org/dataoecd/59/53/36316399.pdf

OECD, (2008), 'Infrastructure to 2030’ Policy Brief http://www.oecd.org/dataoecd/24/1/39996026.pdf

OECD (2009), 'The Economics of Climate Change Mitigation: Policies and Options for Global Action Beyond 2012', www.oecd.org/env/cc/econ/beyond2012

OECD, (2011), 'The Role of Pension Funds in Financing Green Growth Initiatives' http://www.oecd-ilibrary.org/finance-and-investment/the-role-of-pension-funds-in-financing-greengrowth-initiatives_5kg58j11wdjd-en

OECD, (2011a), 'Towards Green Growth', OECD, Paris. http://www.oecd.org/dataoecd/37/34/48224539.pdf

OECD, (2011b), 'OECD Green Growth Studies: Energy', OECD, Paris.

OECD, (2011c), 'Pension Funds Investment in Infrastructure: A Survey' http://www.oecd.org/dataoecd/59/33/48634596.pdf

OECD (2012), 'OECD Environmental Outlook to 2050', OECD, Paris.

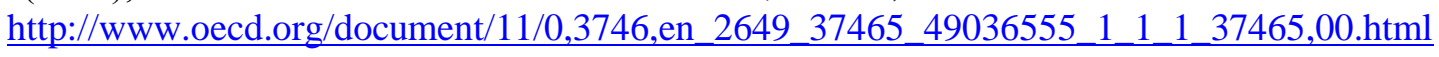

OECD, (2012a - forthcoming), 'Policy Framework for Green Infrastructure Investment' by J. CorfeeMorlot, V. Marchal, C. Kauffmann, C. Tebar Less, F. Stewart, C. Kennedy, C. Kaminker , OECD Working Paper, Paris.

OECD, (2012b - forthcoming), 'Defining and Measuring Institutional Investors' Allocations to Green Investments', OECD, Paris.

OECD (2012c) 'Tracking Climate Finance: What and How?'. OECD, Paris.

OECD, (2012d - forthcoming), 'Kennedy Report'. OECD, Paris.

OECD (2012e - forthcoming), 'Largest Pension Funds 2011 Survey'. OECD, Paris.

OECD, (2012f- forthcoming), 'The Effect of Solvency Regulation and Accounting Standards on Longterm Investing'. OECD, Paris. 
Parhelion Underwriting Ltd and Standard \& Poor's (2010), 'Can Capital Markets Bridge the ClimateChange Financing Gap?'.

Parhelion Underwriting Ltd (2012), 'The Role of Insurance in Climate Policy'

Stern, N. 'The Economics of Climate Change: The Stern Review' (2007)

United Nations High Level Advisory Group on Climate Change, (UN AGF) (2010a), 'Report to the Secretary-General "s High-Level Advisory Group on Climate Change Financing' http://www.un.org/wcm/content/site/climatechange/pages/financeadvisorygroup/pid/13300

United Nations Environment Programme (UNEP), (2009), 'Catalysing Low-carbon Growth in Developing Economies: Public Finance Mechanisms to Scale up Private Sector Investment in Climate Solutions' http://www.energy-base.org/fileadmin/media/sefi/docs/publications/PublicPrivateWeb.pdf

United Nations Environment Programme Finance Initiative (UNEP FI) (2009) 'Green Paper on Financing a Global Deal on Climate Change’ http://ccsl.iccip.net/financing_global_deal.pdf

Veys, A., (2010), 'The Sterling Bond Markets and Low Carbon or Green Bonds' http://www.e3g.org/images/uploads/The_Sterling_Bond_Markets.pdf

Weitzman, M. L.(2011), 'Fat-Tailed Uncertainty in the Economics of Catastrophic Climate Change'. Review of Environmental Economics and Policy 5, no. 2 (January 7, 2011): 275-292. http://www.economics.harvard.edu/faculty/weitzman/files/REEP2011\%2Bfat-tail.pdf

World Economic Forum (WEF), (2011), 'The Future of Long-term Investing': http://www3.weforum.org/docs/WEF_FutureLongTermInvesting_Report_2011.pdf

World Economic Forum, (2010), 'Green Investing 2010'. 


\section{WORKING PAPERS PUBLISHED TO DATE}

The full series is listed below in chronological order. Prior to March 2010, the series was named OECD Working Papers on Insurance and Private Pensions. All working papers can be accessed online at: www.oecd.org/daf/fin/wp.

\section{2}

WP 22: Financial Education, Savings and Investments: an Overview

WP 21: Identification and Assessment of Publicly Available Data Sources to Calculate Indicators of Private Pensions

WP 20: Coverage of Private Pension Systems: Evidence and Policy Options

WP 19: Annual DC Pension Statements and the Communications Challenge

WP 18: Lessons from National Pensions Communication Campaigns

WP17: Review of the Swedish National Pension Funds

WP16: Current Status of National Strategies for Financial Education: A Comparative Analysis and Relevant Practices

WP15: Measuring Financial Literacy: Results of the OECD INFE Pilot Study

WP14: Empowering Women Through Financial Awareness and Education

\section{1}

WP13: Pension Funds Investment in Infrastructure: Policy Actions

WP12: Designing Optimal Risk Mitigation and Risk Transfer Mechanisms to Improve the Management of Earthquake Risk in Chile

WP11: The Role of Guarantees in Defined Contribution Pensions

WP10: The Role of Pension Funds in Financing Green Growth Initiatives

WP9: Catastrophe Financing for Governments

WP8: Funding in Public Sector Pension Plans - International Evidence

WP7: Reform on Pension Fund Governance and Management: The 1998 Reform of Korea National Pension Fund

2010

WP6: Options to improve the governance and investment of Japan's Government Pension Investment Fund WP5: The New IAS 19 Exposure Draft

WP4: The EU Stress Test and Sovereign Debt Exposures

WP3: The Impact of the Financial Crisis on Defined Benefit Plans and the Need for Counter-Cyclical Funding Regulations

WP2: Assessing Default Investment Strategies in Defined Contribution Pension Plans

WP1: Framework for the development of financial literacy baseline surveys: A first international comparative analysis

\section{OECD Working Papers on Insurance and Private Pensions}

WP41: Policy Action in Private Occupational Pensions in Japan since the Economic Crisis of the 1990s WP40: Pension Funds' Risk-management Framework: Regulation and Supervisory Oversight WP38: Managing investment risk in defined benefit pension funds 
WP37: Investment Regulations and Defined Contribution Pensions

WP36: Private Pensions and Policy Responses to the Financial and Economic Crisis

WP35: Defined-contribution (DC) arrangements in Anglo-Saxon Countries

WP34: Evaluating the Design of Private Pension Plans: Costs and Benefits of Risk-Sharing

WP33: Licensing Regulation and the Supervisory Structure of Private Pensions: International Experience and Implications for China

WP32: Pension Fund Investment in Infrastructure

WP31: Pension Coverage and Informal Sector Workers: International Experiences

WP30: Pensions in Africa

\section{8}

WP29: Ageing and the Payout Phase of Pensions, Annuities and Financial Markets

WP27: Fees in Individual Account Pension Systems: A Cross-Country Comparison

WP26: Forms of Benefit Payment at Retirement

WP25: Policy Options for the Payout Phase

WP24: National Annuity Markets: Features and Implications

WP23: Accounting for Defined Benefit Plans: An International Comparison of Exchange-Listed

Companies

WP22: Description of Private Pension Systems

WP21: Comparing Aggregate Investment Returns in Privately Managed Pension Funds: an initial assessment

WP20: Pension Fund Performance

WP19: Coverage of Funded Pension Plans

WP18: Pension Fund Governance: Challenges and Potential Solutions

WP17: Funding Regulations and Risk Sharing

WP16: Evaluating the Impact of Risk Based Funding Requirements on Pension Funds

WP15: Governance and Investment of Public Pension Reserve Funds in Selected OECD Countries

WP14: Reforming the Valuation and Funding of Pension Promises: Are Occupational Pension Plans Safer?

2007

WP13: Pension Fund Investment in Hedge Funds

WP11: Implications of Behavioural Economics for Mandatory Individual Account Pension Systems

WP10: Portfolio Investment in an Intertemporal Setting: Assessment of the Literature and Policy Implications for Latin American Pension Systems

WP9: Collective Pension Funds: International Evidence and Implications for China's Enterprise Annuities Reform

WP8: Pension Fund Regulation and Risk Management

WP7: Survey of Investment Choice by Pension Fund Members

WP6: Benefit Protection: Priority Creditor Rights for Pension Funds

WP5: Benefit Security Pension Fund Guarantee Schemes

WP4: Governments and the Market for Longevity-Indexed Bonds

WP3: Longevity Risk and Private Pensions

WP2: Policy Issues for Developing Annuities Markets

2006

WP1: Funding Rules and Actuarial Methods 